Historic, Archive Document

Do not assume content reflects current scientific knowledge, policies, or practices. 



\subsection{1}

\section{CHRYSANTHEMUMS FOR EVERY PURPOSE 1916}



ARTISTA

\section{ELMER D. SMITH \& CO.}

ADRIAN, MIGHIGAN, U. S. A. 


\section{TERMS OF SALE}

\section{IMPORTANT--READ CAREFULLY}

All plants are grown in 21/4-inch pots, and delivered as soon as they are strong enough.

Kindly remit full amount. It benefits the customer, as we allow 5\% discount for cash with order. Remittances should be made by Postoffice or Express money order or Draft. All letters containing money should be sent by registered mail. Thcse desiring to open an account must send references, preferably from banks or firms with whom credit relations have existed. We do not ship plants C. O. D. unless assured of acceptance by a remittance of $25 \%$ of the amount of the order.

TRANSPORTATION.-In most cases plants travel better and are more satisfactory to the recipient when forwarded by Express, and we recommend this method above all others. We invariably ship by express unless otherwise instructed.

EXPRESS FACILITIES.-Our local companies are the American and Wells-Fargo, who, under the new schedule, agree to transport and deliver plants, either themselves or by the assistance of the Adams. Canadian, Canadian Northern, Dominion, Globe, Great Northern, National, Northern, Southern and Western Express Companies, to destination; the rate being the same when handled by one or more companies and whether sent collect or prepaid.

PARCEL POミT.-Many have been misled in the belief that parcel post is cheaper than express. There are but two cases where it is less: first, small packages of five pounds or less; second, shipments to the first three zones, or within 300 miles from Adrian.

The following table shows amount of charges by Express and Parcel Post:

\begin{tabular}{|c|c|c|c|c|c|c|c|}
\hline & \multirow[b]{2}{*}{ Zones } & \multicolumn{2}{|c|}{$-5 \mathrm{lbs}$} & \multicolumn{2}{|c|}{$-10 \mathrm{lbs}$} & \multicolumn{2}{|c|}{$20 \mathrm{lbs}}$. \\
\hline & & Exp. & P.P. & Exp. & P.P. & Exp. & P.P. \\
\hline Baltimore .... & 4 & $\$ 0.29$ & $\$ 0.23$ & $\$ 0.29$ & $\$ 0.45$ & $\$ 0.42$ & $\$ 0.83$ \\
\hline Boston & $\ldots .5$ & .30 & .32 & .30 & .62 & .46 & 1.22 \\
\hline Denver & 6 & .41 & .41 & .47 & .81 & .78 & 1.61 \\
\hline Indianapolis & ….. 3 & .25 & 14 & .25 & .24 & .30 & .44 \\
\hline Phoenix ........... & ...... 7 & .50 & .51 & .75 & 1.01 & 1.34 & 2.01 \\
\hline San Francisco & ...... 8 & .67 & .60 & .85 & 1.20 & 1.50 & 2.40 \\
\hline
\end{tabular}

From the fcregoing it will be seen that the longer the haul and the heavier the package the greater the saving when shipped by Express.

To localities not reached by express we will forward by Parcel Post, but we cannot become responsible for their delivery. All such shipments must be prepaid and will travel solely at owner's risk.

NO GUARANTEE.-While we exercise the utmost care in executing all orders, to keep our stock true to name, we give no warranty, expressed or implied, and cannot guarantee or be in any way responsible for the crop, either as to variety or product. If not accepted on these terms they must be returned at once. 


\section{ORDER SHEET}

While we exercise the utmost care in execut. ing all orders to keep our stock true to name, we give no warrantee, express or implied, and cannot guarantee or be in any way responsible for the crop, either as to variety or product. If not accepted on these terms, return the goods at oncc.E. D. S. \& Co.

\section{Elmer D. Smith \& Co. Adrian, Mich}

FOR INSTRUCTIONS REGARDING THE SHIPMENT OF PLANTS SEE INSIDE OF FIRST COVER

DO NOT WRITE IN THIS SPACE

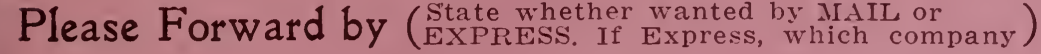

To (In Ordering or Writing, always sign name in the same way.)

Street P. O. Box, or Rural Delivery

Post Office

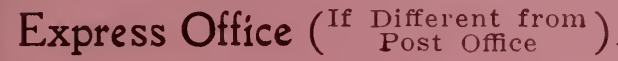

County

State

Date_ $\quad \begin{aligned} & \text { Amount } \\ & \text { Enclosed }\end{aligned} \begin{cases}\text { M. O._Cash_ Discount if taken } \\ \text { Check__ Stamp:s }\end{cases}$




\section{TERMS OF SALE}

\section{IMPORTANT--READ CAREFULLY}

All plants are grown in 21/4-inch pots, and delivered as soon as they are strong enough.

Kindly remit full amount. It benefits the customer, as we allow 5\% discount for cash with order. Remittances should be made by Postoffice or Express money order or Draft. All letters containing money should be sent by registered mail. These desiring to open an account must send references, preferably from banks or firms with whom credit relations have existed. We do not ship plants C. O. D. unless assured of acceptance by a remittance of $25 \%$ of the amount of the order.

TRANSPORTATION.-In most cases plants travel better and are more satisfactory to the recipient when forwarded by Express, and we recommend this method above all others. We invariatly ship by express unless otherwise instructed.

EXPRESS FACILITIES.-Our local companies are the American and Wells-Fargo, who, under the new schedule, agree to transport and deliver plants, either themselves or by the assistance of the Adams, Canadian, Canadian Northern, Dominion, Globe, Great Northern, National, Northern, Southern and Western Express Companies, to destination; the rate being the same when handled by one or more companies and whether sent collect or prepaid.

PARCEL POミT.-Many have been misled in the belief that parcel post is cheaper than express. There are but two cases where it is less: first, small packages of five pounds or less; second, shipments to the first three zones, or within 300 miles from Adrian.

The following table shows amount of charges by Express and Parcel Post:

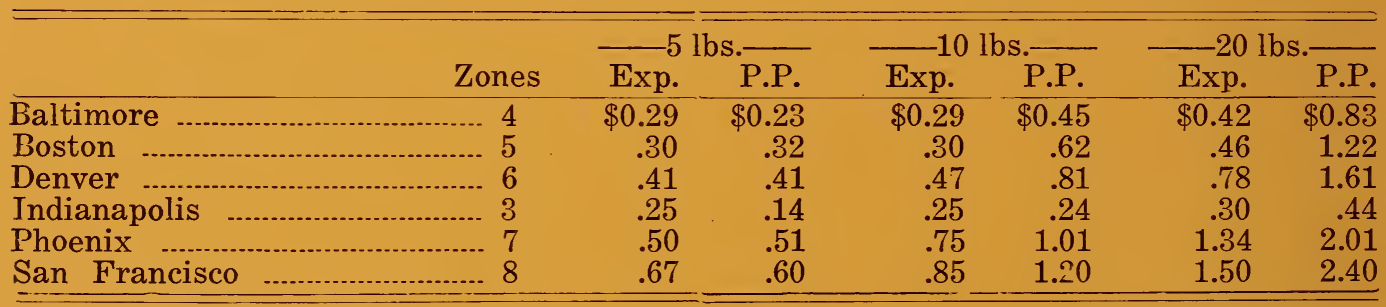

From the fcregoing it will be seen that the longer the haul and the heavier the package the greater the saving when shipped by Express.

To localities not reached by express we will forward by Parcel Post, but we cannot become responsible for their delivery. All such shipments must be prepaid and will travel solely at owner's risk.

NO GUARANTEE.-While we exercise the utmost care in executing all orders, to keep our stock true to name, we give no warranty, expressed or implied, and cannot guarantee or be in any way responsible for the crop, either as to variety or product. If not accepted on these terms they must be returned at once. 


\section{To Our Correspondents:}

In presenting you our descriptive Catalogue for 1916, we wish to express our appreciation for the liberal patronage extended us, and shall endeavor to merit this confidence by continued evidence of our fair and honorable methods.

Chrysanthemums hare been our specialty for many years. Narch 1st, 1850, we sent out our first Chrysanthemum novelty, so that March; 1916, will De our twenty-sixth anniversary in the production and distribution of norelties. Our activities along these lines have been continued with such vigor and the results of our efforts of such high standards that every Florist and Gardener is fully conversant with our products. It was not until 1908 that we gave consideration to seedlings solely adapted to Exhibition purposes. From those selected at that time and subsequent years, we have sent out since 1911 such varieties as Lenox, Glen Core, Christy Mathewson, Nakota, Elberon, Nerissa, Odessa, Kewanee, Silver King, Mankato and Calumet, all of which are unsurpassed for this purpose. Our norelties for 1916 possess the same high standard of excellence that has so long characterized our products. WTe have revised our list of standard varieties, climinating some which are superseded by improved kinds.

Thanking our many friends and patrons for past farors and soliciting their continued patronage, we are,

Yours respectfully,

ELMER D. SMITH \& CO., Adrian, Mich.

P. S.-We are the only firm in America growing Chrysanthemums exclusively.

\section{KEEP THIS CATALOGUE FOR REFERENCE.}

This Catalogue is really a book of reference, giving the height the plants attain, and the best bud to reserve for the many sorts offered. Such information is eagerly sought each year, and especially so as the time for securing buds draws near. Every word in this Catalogue from cover to cover is worth reading and may throw light upon some subject important to the recipient.

Florists are entitled to wholesale prices and will be furnished list on application. Letter heads, business card or other evidence to establish this fact is all that is required. 


\section{EXHIBITION SEGTION}

\section{New American \\ Chrysanthemums for 1915 \\ Originated by Elmer D. Smith \& Co.}

Delivery on or kefore February 1st. Not less than 5 plants of a variety at ten and 25 at hundred rate.

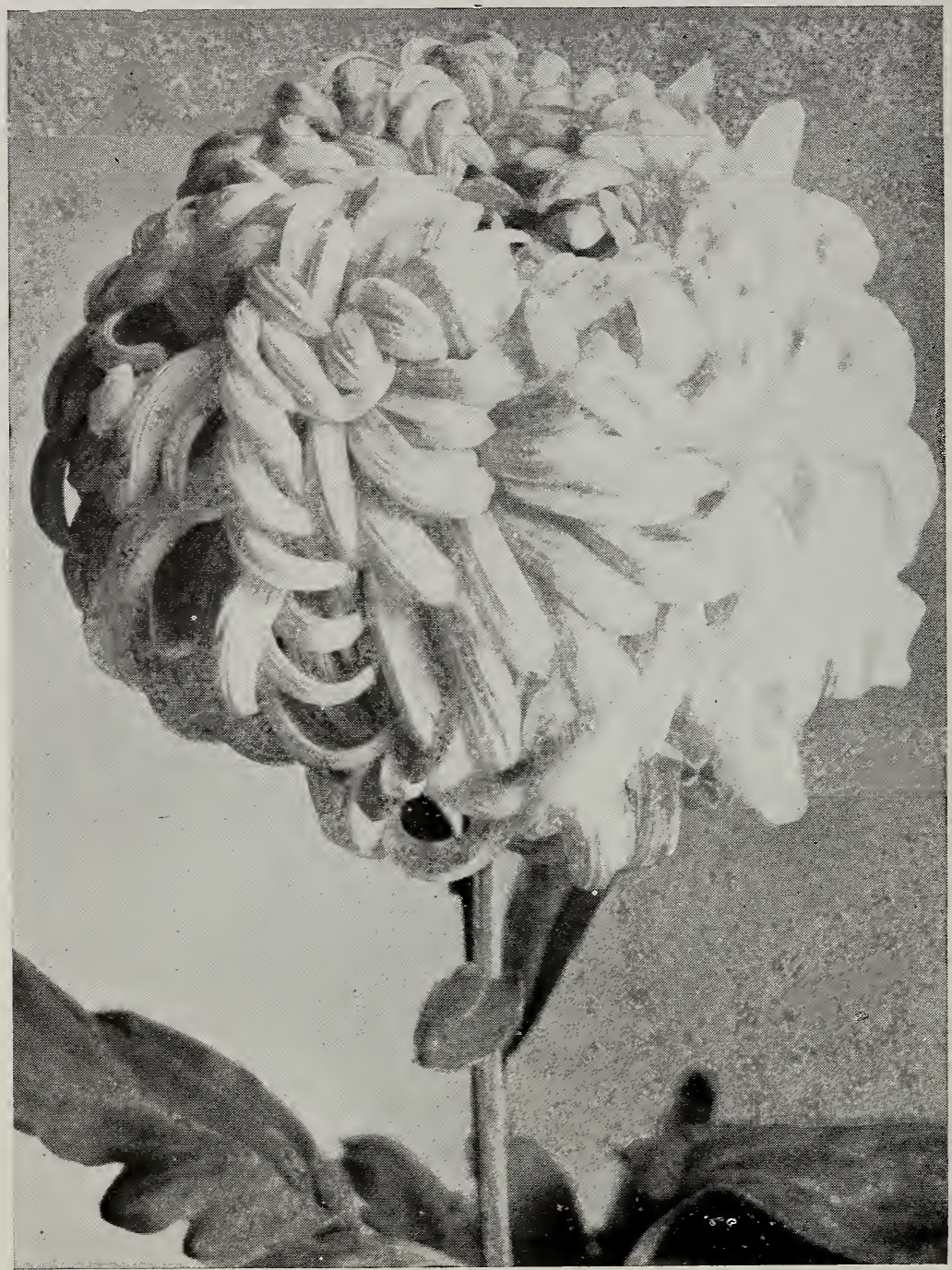

OGONTL.-A seedling from Nakota which it greatly resembles in foliage, and has the same whirling arrangement of petals, with size equal to its parent. The petals are decidedly grooved or channeled. Color, light primrose, height $6 \mathrm{ft}$. Would not advise a bud eariler than August 30th as the blooms are double from those selected in September. Practically the same as Nakota except color, maturing first week of November. May also be advantageously grown as a commercial, maturing November 20 th from buds taken September 20th and after.

$\$ 1.50$ each; $\$ 12.50$ per ten; $\$ 100.00$ per hur.dred. 
ARTISTA.-This, we believe, is the largest Exhibition variety we have ever raised and doubt if it will be surpassed by any now grown, not excepting Wm. Turner, Odessa, etc. Outer petals grooved or channeled, reflex while the center ones incurve irregularly giving a very artistic appearance to the bloom. Dwarf habit, will not attain over $5 \mathrm{ft}$. from February propagation. White with a slightly creamy tint in the depths. Best bud August 20th, maturing the last days of October. All exhibition growers are bound to accept this as one of the best.

$\$ 1.50$ each; $\$ 12.50$ per ten; $\$ 100.00$ per hundred.

YELLOW TURNER.-The variety Wm. Turner has sported in at least six remote places during the past two years. Some of these are very light, hardly cream color. Our stock is the darkest yellow we have seen, being about the same as Mrs. J. C. Neill or F. S. Vallis. In other respects it is identical with Wm. Turner.

$\$ 1.50$ each; $\$ 12.50$ per ten; $\$ 100.00$ per hundred.

\section{INTRODUCTION OF 1915}

50c each; $\$ 4.00$ per ten; $\$ 35.60$ per hundred, except where otherwise quoted.

Not less than 5 plants of a variety at ten, and 25 at hundred rate.

ALGONAC.-White with a slightly creamy tint at center. High rounded incurved blooms. Strong dwarf growth. Best bud Aug. 20th.

ANTIGONE.-Pure white, large double flower. Early midseason, dwarf habit.

BOB PULLING.-Very large, orange yellow, one of the best exhibition sorts. Easy to grow, producing beautiful foliage up to the flower. Best bud Aug. 5 th.

CALUMET.-The best exhibition bronze to date; rather early for late shows, but its large size, the high percentage of perfect blooms and its easy culture make it one of the best. Best bud Aug. 25th.

EARL KITCHENER.-An enormous flower and a color none to plentiful at exhibitions, amaranth with silvery reverse. Best bud Aug. 25th.

KEWANEE.-Color Chamois, very distinct, of large incurved form. Should be in every exhibition collection. Rather tall. Best bud Sept. 5th.

MANKATO.-Purplish Rose or Amaranth of the reflexed form. Sturdy upright growth. Bud Aug. 30th.

MRS. R. C. PULLING.-A light yellow of the largest size; especially adapted for exhibition use where large blooms are required. Bud Aug. 15th.

MRS. EDGAR J. SLATER.-Long reflexed and curling florets of medium width. Color a rich Amber. Bud Aug. 15th.

30c each; $\$ 2 . \overline{0} 0$ per ten; $\$ 20.60$ par hundred.

MRS. J. P. MITCHEL.-Very large reflexed, pure white, admirably adapted for exhibition collections. Bud Aug. 20th.

MRS. LAURA B. MORRIS.-An exception to most yellow sorts, being bright rather than light yellow. Same strong habit as its parent, Thanksgiving Queen. Excellent for late shows. Best bud Sept. 5th.

30 c each; $\$ 2.50$ per ten; $\$ 20.60$ per hundred.

MISS L. M. BENNETT.-Rich Crimson in color with fine stem and foliage and one of the largest of its class. Bud Aug. 15th.

30 c each; $\$ 2.50$ per ten; $\$ 20.60$ per hundred.

MRS. WM. H. WALKER.-Color lemon yellow and one of the very largest. Fine dwarf habit. Bud Aug. 10th.

30c each; $\$ 2.50$ per ten; $\$ 20.00$ per hundred. 


\section{STANDARD VARIETIES}

In selecting the most suitable for exhibition purposes, we have given size and finish first consideration.

We are aware some of the best blooms are produced from buds taken August 5th, but throughout the Middle West buds of most varieties, taken prior to August 15th, suffer from excessive heat and lack of moisture, and for this reason we secure our best results from those taken August 15th to 30th. Each grower must be governed by the conditions in his immediate locality, and may find it advantageous to take them earlier than dates given.

In determining the height, those which do not exceed $4 \mathrm{ft}$. are designated as Dwarf; those which do not exceed $6 \mathrm{ft}$. as Semi-Dwarf, and those growing taller as Tall. These cieductions are only approximate and from stock propagated in February. .

10c each; 80c per ten; $\$ 6.00$ per hundred. Unless otherwise noted.

Not less than 5 plants of a variety at ten, 25 at hundred rate.

Best Bud

8/5 Alice Lemon.-A soft shade of pink and of the largest size. Very early bud is imperative, otherwise it is single. Dwarf.

20c each; \$1.75 per ten; \$12.00 per hundred.

8/15 Annie I. Angus.-Stem rather weak but flowers can be grown to the largest size. Pure white. Dwarf.

8/20 Irtistic Queen.- (Introduced by us 1912.) The blooms are loosely incurved, of the largest size, resting upon heavy foliage and supported by a very rigid stem. Color, a light rose pink. Dwarf.

15e each; \$1.20 per ten; $\$ 10.00$ per hundred.

$\delta / 10$ Ben Wells.-One of the largest exhibition whites. Dwarf.

8/25 Black Hawk.-Dark crimson scarlet, exceptionally fine color. Semi-dwarf.

$8 / 15$ Bronze Brighthurst.-A bronze colored sport of the old favorite Brighthurst. It is the exact duplicate of its parent in stem, foliage and every respect except color. semi-dwarf.

8/10 Cheltoni.-A yellow sport from Nellie Pocket. Dwarf.

8/10 Chas. H. Totty.-Chestnut, with old gold reverse; an easy grower and of large size. Semi-dwarf.

20c each; \$1.75 per ten; $\$ 12.00$ per hundred.

8/15 Christy Matherson.-(Introduced by us 1912.) A Japanese of largest size, eight inches in diameter and six and one-half inches deep. In early development it shows an eye, but continues to produce more petals day by day until the center is filled. Pure white. Strong, wiry stem. Semi-dwarf.

8/20 Chrysanthemiste Montigny.-A large Japanese incurved; light sulphur yellow. Tall. 15e each; $\$ 1.20$ per ten; $\$ 10.00$ per hundred.

S/10 Countess of Granard.-Rich yellow, a huge flower of first quality. Partakes of F. S, Vallis, but superior. Good habits, stem and foliage. Tall. 15c each; $\$ 1.20$ per ten. $\$ 10.00$ per hundred.

Daily Mail.- An extra large incurved yellow. Very tall grower with heavy foliage. The stem is scarcely strong enough to sustain the bloom, but for short stem collections will be very acceptable owing to its size and finish. Tall. 15e each; $\$ 1.20$ per ten. \$10.00 per hundred.

8/25 Dakoma.-(Introduced by us 1907.) A fine exhibition bronze, of large size and beautiful form. Dwarf. 15c each; $\$ 1.20$ per ten. $\$ 10.00$ per hundred.

8,10 D. B. Crane-Deep golden yellow, slightly streaked with red, petals recurving at tips. Makes a flower of largest size and finest form. Dwarf. 20c each; $\$ 1.75$ per ten; $\$ 12.00$ per hundred.

8/25 Dragon Vert.-A large crimson with golden reverse; petals are regular and full in their arrangement. Stiff stem and a free grower. Dwarf. 25c each; $\$ 2.00$ per ten; $\$ 15.00$ per hundred. 


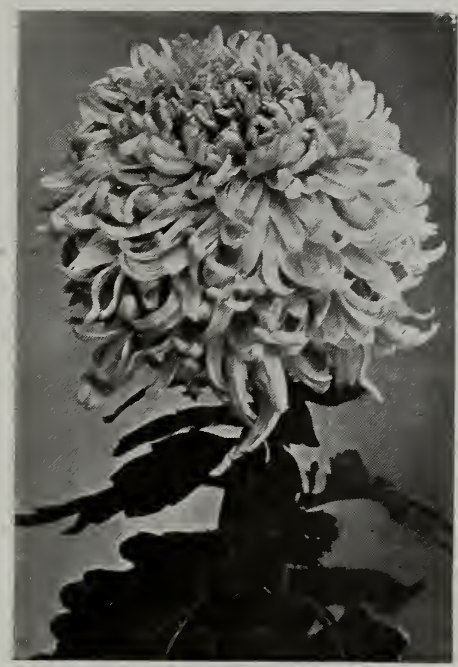

Glen Cove.

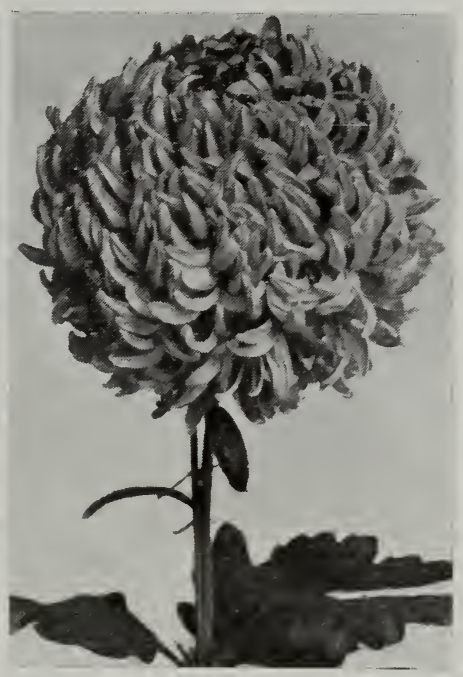

Calumet.

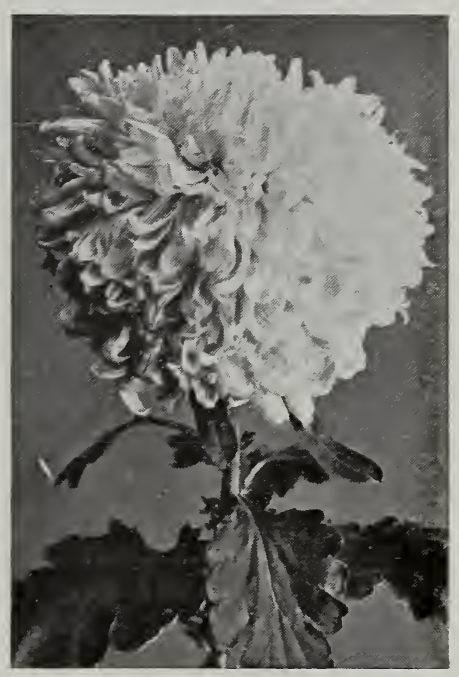

Silver Kings.

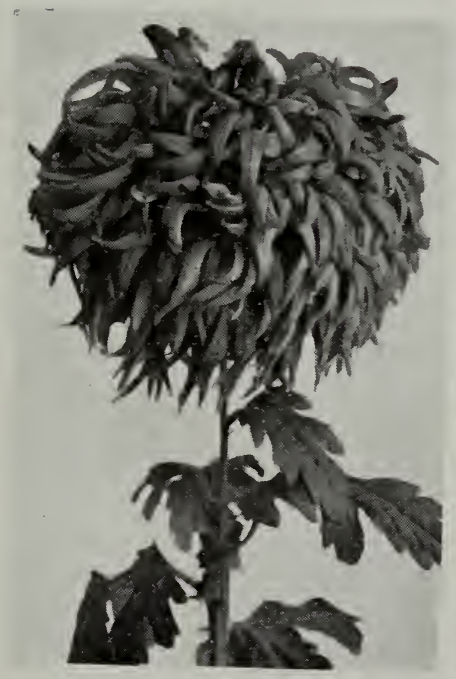

Mankato.

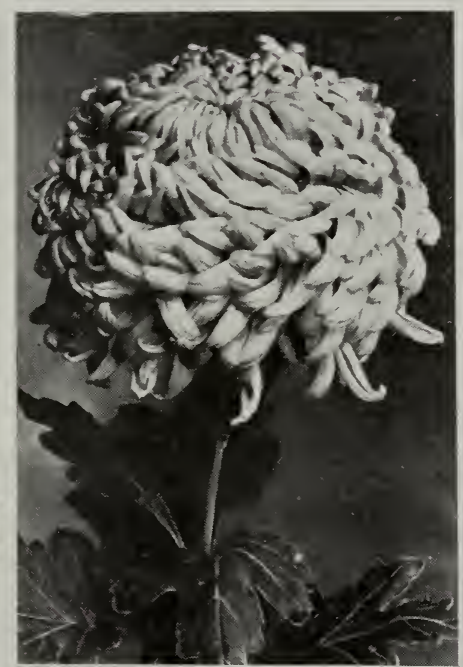

Nakota.

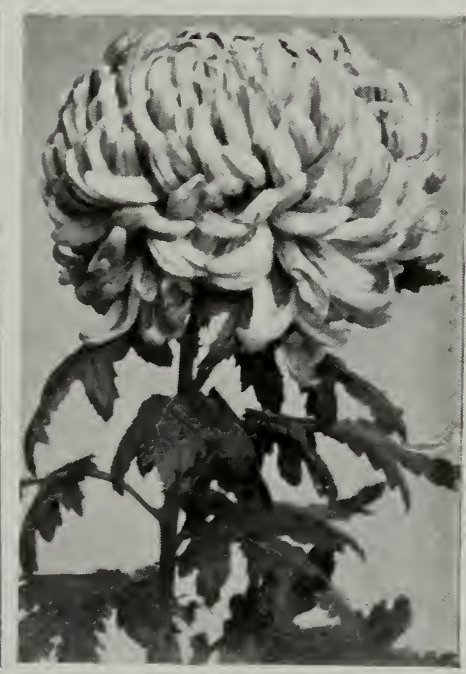

Nerissa.

All quotations given are for strong plants from $21 / 4$-in. pots, unless otherwise specified. These are forwarded by express unless we have explicit instructions to ship otherwise. See terms of sale inside of front cover.

Owing to the increased demand we have provided a large stock of the most popular standard kinds. Under these conditions we hope to be able to supply our patrons promptly with plants of the highest quality. 
8/25 Elberon.-(Introduced by us 1913.) We have received from last year's purchasers many strong endorsements as to the merits of this variety as an exhibition sort and we predict it will be more popular when better known. Bright pink with lighter reverse. Semi-dwarf.

8/10 Earnest G. Mocatto.-An immense flower of the F. S. Vallis type, but a much richer yellow. Stem and foliage perfect. Dwarf. 20e each; \$1.75 per ten; \$12.00 per hundred.

S/25 Fatouma-The blooms are irregularly incurved, of a rosy amber color, and of fine build. Full exhibition size, with good stem and foliage. Semi-dwarf. 20 e each; $\$ 1.75$ per ten; $\$ 12.00$ per hundred.

F. E. Nash.-Japanese, light pink, large in size, but, like many other pinks, inclined to be unstable in color, especially on early buds. Dwarf. 15c each; \$1.20 per ten. \$10.00 per hundred.

8/20 Flamingo.-(Introduced by us 1914.) A bright crimson with perfectly reflexed flowers, showing the intense color to best advantage. Dwarf. 25e each; $\$ 2.00$ per ten; $\$ 15.00$ per hundred.

Francis Joliffe.-An enormous flower, creamy yellow petals edged with a broad band of pink. Semi-dwarf.

15 c each ; $\$ 1.20$ per ten. $\$ 10.00$ per hundred.

F. S. Vallis.-A very large yellow, desirable for collections on short stems. Semidwarf.

S/25 Gen. Hutton.-Large Japanese, yellow with bronze shadings. Tall.

8/10 Gertrude Peers.-Of sturdy, upright growth. Color crimson. Semi-dwarf. 15e each; \$1.20 per ten. \$10.00 per hundred.

8/15 Geo. J. Bruzard.-Wine red, broad florets. One of the largest for collections. Semidwarf.

8/20 Glen Cove.-(Introduced by us 1911.) Japanese, light lavender pink; few pinks excel this variety in size, and its sturdy stem admits of staging without supports. Semi-dwarf.

\$/30 Glenview.-The large Japanese blooms are dark bronze, sometimes showing a little of the Indian red lining. It is also a good commercial bronze, giving double flowers from late buds. Semi-dwarf.

8/20 Gorgeous.-A golden-yellow Japanese. Large, broad flowers of fine form. Foliage is short and leathery. Semi-dwarf.

20e each; $\$ 1.75$ per ten; $\$ 12.00$ per hundred.

8/25 Goldnine.-(Introduced by us 1900.) Immense Jap. blooms, with whorled center; richest golden yellow, outer petals reflex. Good for late shows and Thanksgiving. Dwarf.

20e each; $\$ 1.75$ per ten; $\$ 12.00$ per hundred.

9/5 Harry E. Converse.-Growth vigorous, clean foliage, large blooms, petals crimson with golden bronze reverse, which is the predominating color. Semi-dwarf. 20e each; $\$ 1.75$ per ten; $\$ 12.00$ per hundred.

$8 / 5$ Hon. Mrs. Lopes.-Very large yellow, but, like many of the importations, an early bud is important to secure double flowers. Dwarf.

8/25 Howard Gould.-Inside of petals bright golden chestnut. Reverse, pure deep gold. Dwarf.

15e each; \$1.20 per ten. \$10.00 per hundred.

8/5 James Fraser.-A decided reflexed. The long ribbon-like petals hang down to the foliage. Canary yellow; closely resembles F. S. Vallis, but has a much stronger stem; is equally large. Semi-dwarf.

20c each; \$1.75 per ten; $\$ 12.00$ per hundred.

8/10 J. Lock.-Bright yellow, streaked red; broad and long florets, blooms extra large. Dwarf.

15 e each; $\$ 1.20$ per ten. $\$ 10.00$ per hundred.

8/20 Kitty Lawrence.-A delicate fawn color; long petals which curl and interlace, forming a very attractive bloom. Tall. 


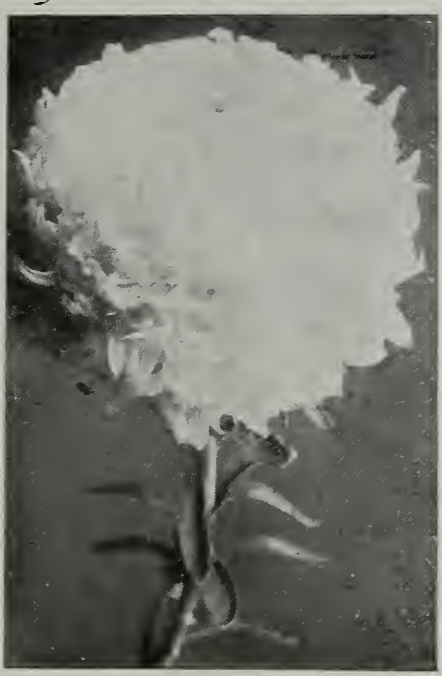

Christy Mathewson.

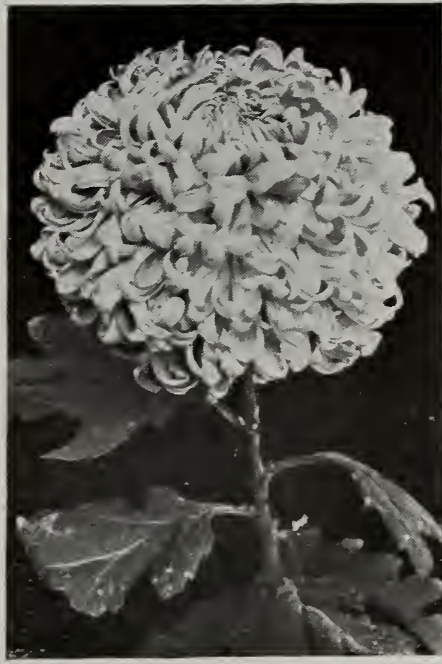

Lenox.

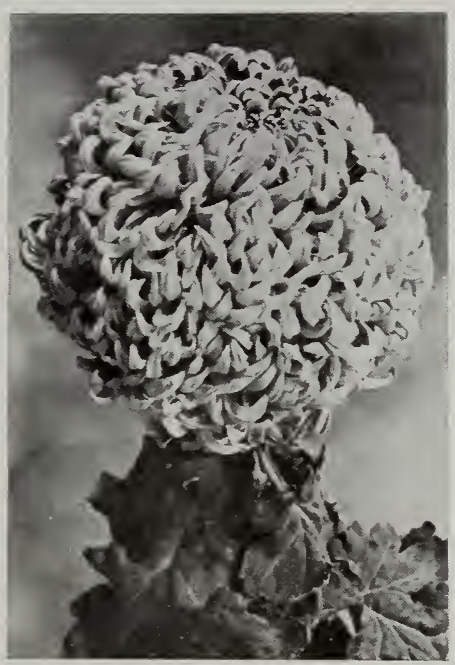

Eiberon.

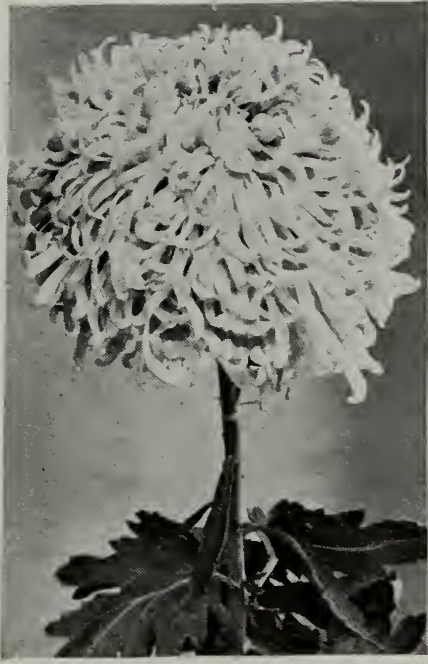

Morristown

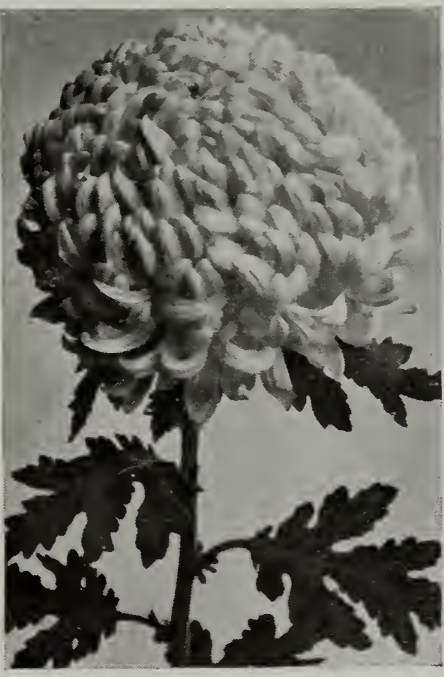

Odessa.

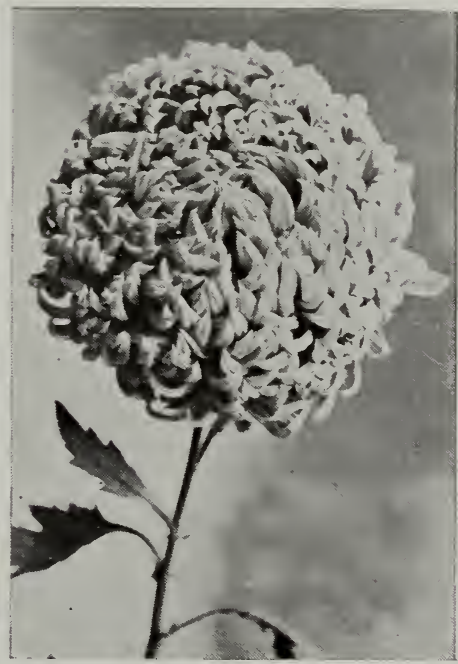

Kewanee.

Remember there are no other novelties offered this season so meritorious as those described on the foregoing pages.

We can supply any of the novelties offered in this country for 1916 at introducers' prices. Should you need others, write us.

We are in receipt of many testimonials complimenting quality of stock, mode of packing and liberal count. Send us a list of your friends interested in chrysanthemums. 
8/15 Lady Carmichael.-Center petals incurving, while outer ones are long and reflex. Color, pure white. Semi-dwarf.

25e each ; $\$ 2.00$ per ten; $\$ 15.00$ per hundred,

S/25 Lady Hopetoun.-Light pink; a very fine-formed bloom. Dwarf.

S 15 Lenox.-(Introduced by us 1911.) The largest yellow known; in fact, there are but a few in our large collection that equal it in size. Beautiful loosely incurved, and a bright, pleasing shade of yellow; many of our blooms are 9 in. in diameter and $7 \frac{1}{2}$ in. in depth; unexcelled for exhibitions. Semi-dwarf.

8/10 Leslie Morrison.-Rosy crimson, with broad, thick florets. Its dark green foliage makes it very attractive. Semi-dwarf.

15 c each; $\$ 1.20$ per ten. $\$ 10.00$ per hundred.

8/25 Lord Ifepetoun.-Bright crimson, with golden reverse; one of the best. Dwarf. 26e each; $\$ 1.75$ per ten; $\$ 12.00$ per humdrcd.

8/30 Lucile Quinlain.-(Introduced by us 1913.) Bright yellow, loosely incurved, and is useful for either exhibition or commercial purposes. Semi-dwarf.

$8 / 15$ I. Loiseau-Rousseau.-Large, incurving pink in two tones of color; fine stem and foliage. Exceedingly large and bold; should be in every collection. Tall.

8/15 Marquis Visconti Venosta.-Beautiful bright pink Japanese incurved; fine for exhibitions. Semi-dwarf.

15̌c each; $\$ 1.20$ per ten. $\$ 10.00$ per hundrcd.

8/15 Mary Donellan.-An excellent Japanese incurved; broad petals of great substance, brightest yellow with reverse of same shade. Tall.

15e each; $\$ 1.20$ per ten. $\$ 10.00$ per hundrcd.

8/15 Mary Mason.-Rosy bronze, with lighter reverse; outer petals reflex, while center ones incurve, showing reverse. Dwarf.

$8 / 30$ Merza.-(Introduced by us 1898.) A fine white for exhibition. Dwarf. 20e each; $\$ 1.75$ per ten; $\$ 12.00$ per hundred.

8/20 Merdon.-Dark pink. Its immense size makes it most acceptable for those interested in exhibitions, especially in the short-stemmed classes. Dwarf.

25e each; $\$ 2.00$ per ten; $\$ 15.00$ per hundred.

8/15 Miss Clay Frick.-White sport from Wm. Duckham, possessing the same good qualities. Free to grow and easy to manage. Dwarf.

15e each; $\$ 1.20$ per ten; $\$ 10.00$ per hundred.

8/25 Miss Mariam Hankey:-Mauve pink Japanese incurved; is inclined to come late. Semi-dwarf.

15 e each; $\$ 1.20$ per ten; $\$ 10.00$ per hundred.

8, 20 Miss Maude Jeffries.-California growers consider this one of the best whites for their use, either commercially or for exhibitions. An incurved pure white. Very dwarf.

8/10 Morristown.-(Introduced by us 1911.) Unsurpassed in size by any pink; long reflexing outer petals with incurved center. When seen at its best it outranks any pink we know of. Semi-dwarf.

8/15 Mount Kisco.- (Introduced by us 1913.) Very useful, whether grown for exhibition or where the late buds are selected for commercial use. Creamy white, strong stem and wonderful keeping qualities. Dwarf.

15e each; $\$ 1.20$ per ten; $\$ 10.00$ per hundred.

8/30 Mount Greenwood.-A mid-season pink. Exceptionally fine in color. In form resembles Chadwick. Dwarf.

20e each; $\$ 1.75$ per ten; $\$ 12.00$ per hundred. 
Mrs: A. M. Henshaw.-A fine incurved white. Stem and foliage perfect. Semi-dwarf. 20c each; $\$ 1.75$ per ten; $\$ 12.00$ per hundred.

Irs. David Syme.-The purest white and of the largest size. Dwarf. 25e each; \$2.00 per ten; $\$ 15.00$ per hundred.

Mrs. Ernest Wild.-Chestnut crimson with bronze reverse. Nice upright growth and clean foliage; very promising. Semi-dwarf. 20c each. $\$ 1.75$ per ten; $\$ 12.00$ per hundred.

Mrs. G. Lloyd Wigg.-Light yellow; one of the largest of this color. Semi-dwarf. 2ce each. $\$ 1.75$ per ten; $\$ 12.00$ per hundred.

Mrs. Geo. W. Burke.-A fine bronzy yellow; stem and foliage all that could be desired; comes good from any bud and is in perfection for the earlier shows. Dwarf.

Mrs. Geo. Hunt.-Large, soft yellow Japanese incurved. A grand exhibition variety of robust growth. Dwarf. 15c each; $\$ 1.20$ per ten; $\$ 10.00$ per hundred.

Mrs. Gilbert Drabble.-This variety conforms in every way to the American ideal; stem rigid, foliage well up to the bloom, and is of the largest size. Purest white in color, and the petals are arranged in a whorl, rendering it most attractive. Dwarf.

$25 c$ each; $\$ 2.00$ per ten; $\$ 15.00$ per hundred.

Mrs. H. Stevens.-A large golden bronze, fine form and perfect finish. Dwarf. 1.5e each; $\$ 1.20$ per ten; $\$ 10.00$ per hundred.

Mrs. Harry Turner.-A lovely crimson, showing a color as deep as the old Black Hawk, with a flower of good size. Stem and foliage perfect. Semi-dwarf. 25e each; \$2.00 per ten; $\$ 15.00$ per hundred.

Mrs. H. J. Jones.- The color is a true chartreuse green when opening. changing to a rich, deep yellow. True Japanese in form, of the largest size. Tall. ace each. $\$ 1.75$ per ten; $\$ 12.00$ per hundred.

Irs. J. E. Dunne.-Salmon terra cotta Japanese; good color and very effective. Tall.

Mrs. J. A. Miller.-A large, high-built Japanese; reddish bronze. Semi-dwarf.

Mrs. J. C. Neill.-A soft canary yellow; fine incurved form; of easy cultivation and one of the best. Semi-dwarf.

Mrs. May Hunter.- Tery popular on the Pacific coast, where it is considered the very best pink for exhibition use. The color is described as that of the La France rose. Tall.

Mrs. O. H. Kahn.-A fine bronze; should not be overlooked by commercial growers. Dwarf.

Mrs. Paul Moore.-Too early for late exhibitions, of dwarf habit and full exhibition size. Color light yellow. Semi-dwarf.

15e each; $\$ 1.20$ per ten; $\$ 10.00$ per hundred.

Mrs. Wm. Duckham.-Large, Japanese reflexed. One of the best exhibition yellows. Dwarf.

Nakota.-(Introduced by us 1913.) popular for exhibition purposes. 
8/10 Nellie Pocket.-Irregular incurved Japanese, narrow twisted petals, creamy white, first bud. Dwarf.

9/5 Nerissa.-(Introduced by us 1914.) Owing to its enormous size, fine form and finish, is conceded to be one of the best exhibition sorts. Color rosy-mauve. Strong, upright growth with rigid stem. Well adapted for specimen plants. Dwarf. 25c each; $\$ 2.00$ per ten; $\$ 15.00$ per hundred.

8/30 Odessa.-(Introduced by us 1914.) A seedling from Merza, but much freer in growth and better in every way. Splendid incurved form, bright yellow. It eclipses all the yellows in size and finish. Equal to Wm. Turner. Tall. 25c each; $\$ 2.00$ per ten; $\$ 15.00$ per hundred.

$8 / 20$ o. H. Broomhead.-A large bloom, with long, broad reflexing petals; color, rose pink. Dwarf. 15e each; $\$ 1.20$ per ten; $\$ 10.00$ per hundred.

8/25 Ongawa.-(Introduced by us 1907.) Color, golden amber; easy to grow; fine stem and foliage. One of the best for the Pacific Coast. Semi-dwarf. 15e each; \$1.20 per ten; $\$ 10.00$ per hundred.

$8 / 30$ Perle Francaise.-Enormous in size, petals reflexing and curling at tips. Color, soft lavender pink, shading to white. Semi-dwarf. 15e each; $\$ 1.20$ per ten; $\$ 10.00$ per hundred.

\$/30 Petite Marcel.-This variety belongs to the "Rayonante" section, with a spread like a dinner-plate, each series of petals shorter toward the center; color, rosymauve. A wonder for collections; straight, thread-like petals. Dwarf. 15e each; $\$ 1.20$ per ten; $\$ 10.00$ per hundred.

8/10 Pceketl's Crimson.-Crimson with gold at tips of petals, which stand out, showing the color to good advantage. Dwarf.

15e each; \$1.20 per ten; $\$ 10.00$ per hundred.

\$/25 Fockett's Surprise.-Rosy crimson with cinnamon bronze reverse; long, broad florets. Japanese incurved; foliage heavy and good.stem. Semi-dwarf. 15e each; \$1.20 per ten; \$10.00 per hundred.

8/15 Poughkeepsie.-(Introduced by us 1911.) Full exhibition size; in fact, is larger than Merza. White, with slightly creamy cast. Tall. 15e each; $\$ 1.20$ per ten. $\$ 10.00$ per hundred.

S/30 Pres. Taft.-(Introduced by us 1909.) Japanese incurved, petals of the purest white, which closely incurve; stem and foliage good. Semi-dwarf.

8/25 Reginald Vallis.-A large Japanese, plum color with lighter reverse. Can be grown to enormous size with excellent finish. Tall.

15e each; $\$ 1.20$ per ten. $\$ 10.00$ per hundred.

$8 / 25$ R. F. Felton.-Color exceptionally good, very intense yellow. Tall. 15e each; $\$ 1.20$ per ten. $\$ 10.00$ per hundred.

8/15 Rose Pockett.-Light shade of yellow, with an ocasional tint of bronze. The wide petals incurve at the center and the outer ones reflex. Semi-dwarf.

$8 / 25$ T. Carrington.-Growth vigorous, amaranth, large. Owing to its distinct color, is unrivalled for classes calling for any other color than white, pink, yellow, etc. Semi-dwarf.

15c each; $\$ 1.20$ per ten. $\$ 10.00$ per hundred.

8/20 Tarrytown.-(Introduced by us 1911.) Large, light rosy salmon of a pleasing shade; quite similar to that of W. A. Etherington. Petals irregularly arranged. Dwarf. 
9/10 Thanksgiving Queen.-(Introduced by us 1911.) Very large, creamy white, and comes just right for Thanksgiving. Strong stem, and so upright and sturdy in growth as scarcely to require tying. Dwarf.

$8 / 20$ Wells, Late Pink.-A very pleasing shade of pink and of the largest size; not late as the name implies. Dwarf.

8/15 White Cloud.-(Introduced by us 1908.) A very large, pure white; rather loose bloom, creamy center, good stem and foliage. Semi-dwarf.

8/15 Wm. Duckhanı.-Beautiful light pink, Japanese incurved. Owing to its freedom of growth, pleasing color and sturdy stem, is deservedly popular. Dwarf. 15 each; $\$ 1.20$ per ten. $\$ 10.00$ per hundred.

8,30 Wm. Turner.-A decided incurve of the purest white; fine form and a strong grower with clean foliage. Semi-dwarf.

$8 / 20$ Wm. Vert.-Bright crimson of large size; form reflexed; growth strong. Semidwarf.

15e each; $\$ 1.20$ per ten. $\$ 10.00$ per hundred.

8/5 W. Woodmason.-The largest red; not as bright in color as many of the crimsons, but its size enhances its value. Dwarf. 15e each; $\$ 1.20$ per ten; $\$ 10.00$ per hundred. good. Semi-dwarf.

\section{GHRYSANTHEMUMS COLLECTIONS}

To those desiring a large collection of the choicest varieties at greatly reduced rates, we make the following Special Offers. We are confident these collections will please the most fastidicus, not only in the selection, but quality of stock. In considering these do not overlook the fact that the noveties included are not merely socalled Novelties, but those approved by the best growers in this country and abroad.

No change made in these collections, and selections of varieties in all cases must be left to us. Prices quoted are NET cash.

No. 1. Five American Novelties 1916; 5 Novelties 1915. Twenty-five: Exhibition varieties; 5 Anemones; 5 Pompons; 5 Singles; 50 plants

No. 2. Ten Novelties of 1915; 25 Exhibition

No. 3. Forty Best Exhibition standard varieties

No. 4. Twenty Best Exhibition standard varieties............................................... 1.50

No. 5. Ten Best Exhibition standard varieties........................................................... . .75

No. 6. Ten Best Anemones .............................................................................................. .50

No. 7. Ten Best Pompons

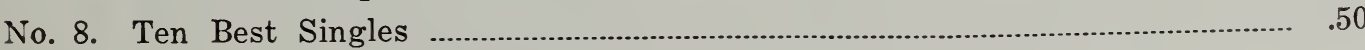




\section{COMMERCIAL SECTION}

The varieties best suited for the commercial grower are those which have sturdy, upright growth, with good stem and foliage, are of p'easing color and (with the exception of a few early varieties) produced double flowers from the late or terminal bud. We have endeavored to give the height the plants attain and best date to reserve buds. In glving the height it must be considered only approximate, as much depends upon the size of plants at planting time and corditicns maintained thereafter.

\section{New American Chrysanthemums for 1916 \\ Orginated by Elmer D. Smith \& CO.}

Delivery on or kefore March 1st. Not less than 5 plants of a variety at ten, and 25 at hundred rate.

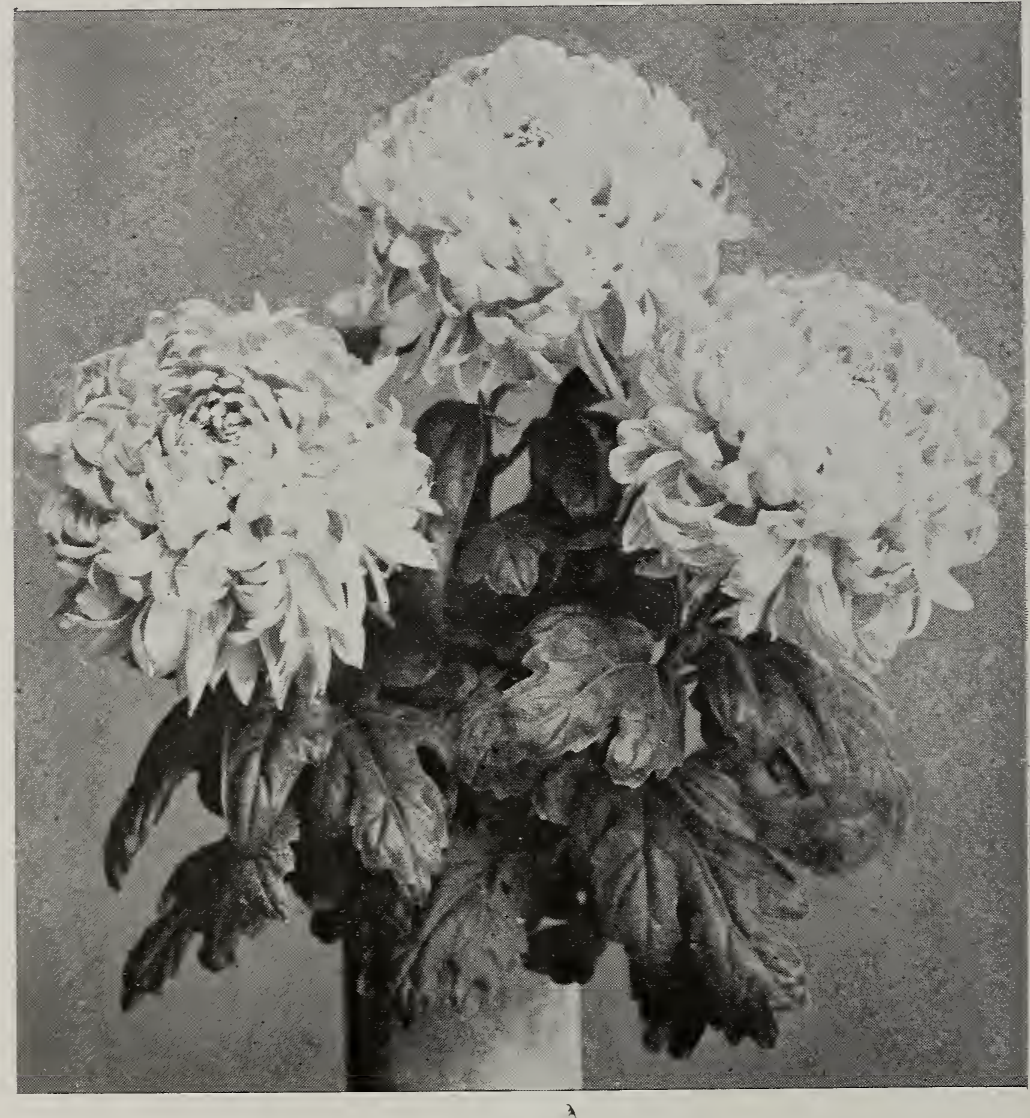

EARLY ROSE.-A seedling from Smith's Advance. Rose color, as the name implies, of a bright pleasing shade under all conditions of light. Form incurved, size six inches. Stem and foliage excellent. Dwarf habit $2 \frac{1 / 2}{2}$ to $3 \mathrm{ft}$. high. There are but few pinks maturing before October 15th and most of these are unsatisfactory unless the bud is selected at the proper date, being off-colored if too early or single from late kuds. Best bud Aug. 20th, producing fully matured flowers in six weeks and double from all buds this date and after. C. S. A. Certificate. 


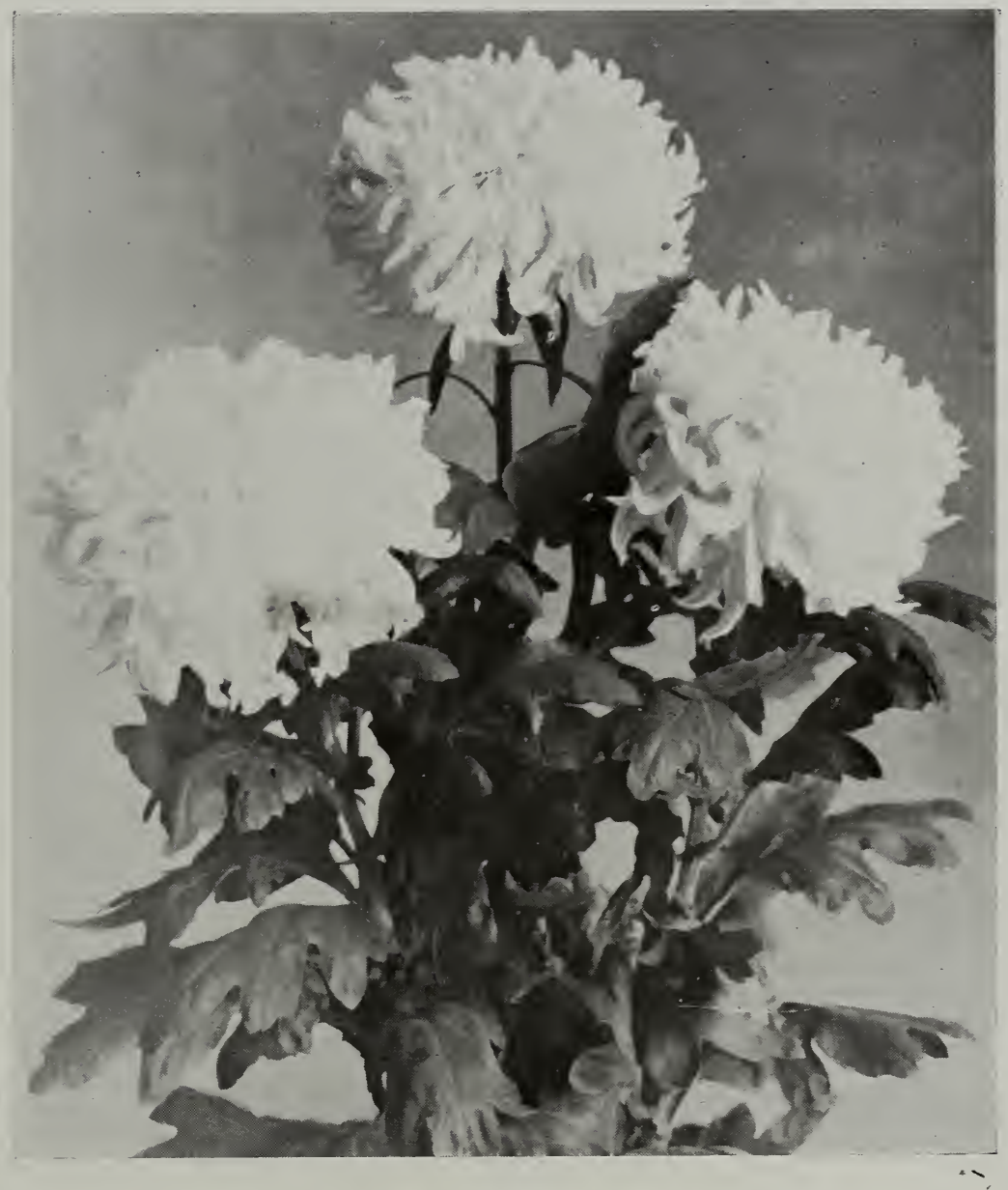

OCTOBER QUEEN.-This belongs to the Japanese section with an inclination to incurve at the center, especially from September buds. One of the purest whites we know of. Maturing October 15th, height $5 \mathrm{ft}$. This variety has been scored 93 points. Having been given full number on color, stem and foliage. Best bud Aug. 25th. 


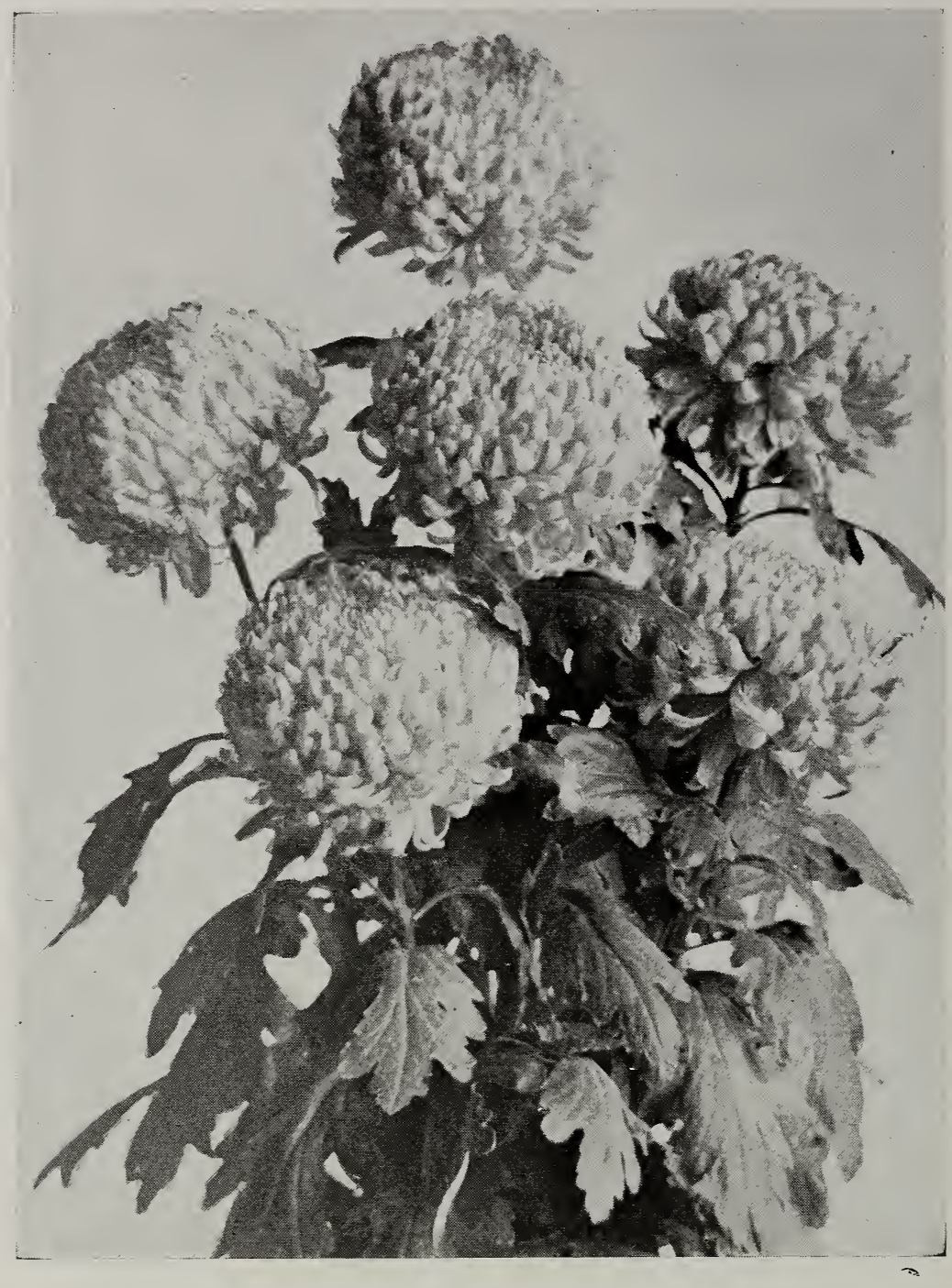

TIGER.-Pres. Wilson kindly supplied the name for this new yellow. A seedling from Chrysolora, being several shades darker than its parent. It is supremely fitted for the rank and file of growers, especially those who are unable to plant early, as its characteristics stamp it as a commercial of special merit. Fine incurved form, producing flowers double to the center from September buds, sturdy semi-dwarf growth, with beautiful foliage and very rigid stem. Height about 4 ft., from June 1st plantings. Best bud September 5th. C. S. A. Certificate. 


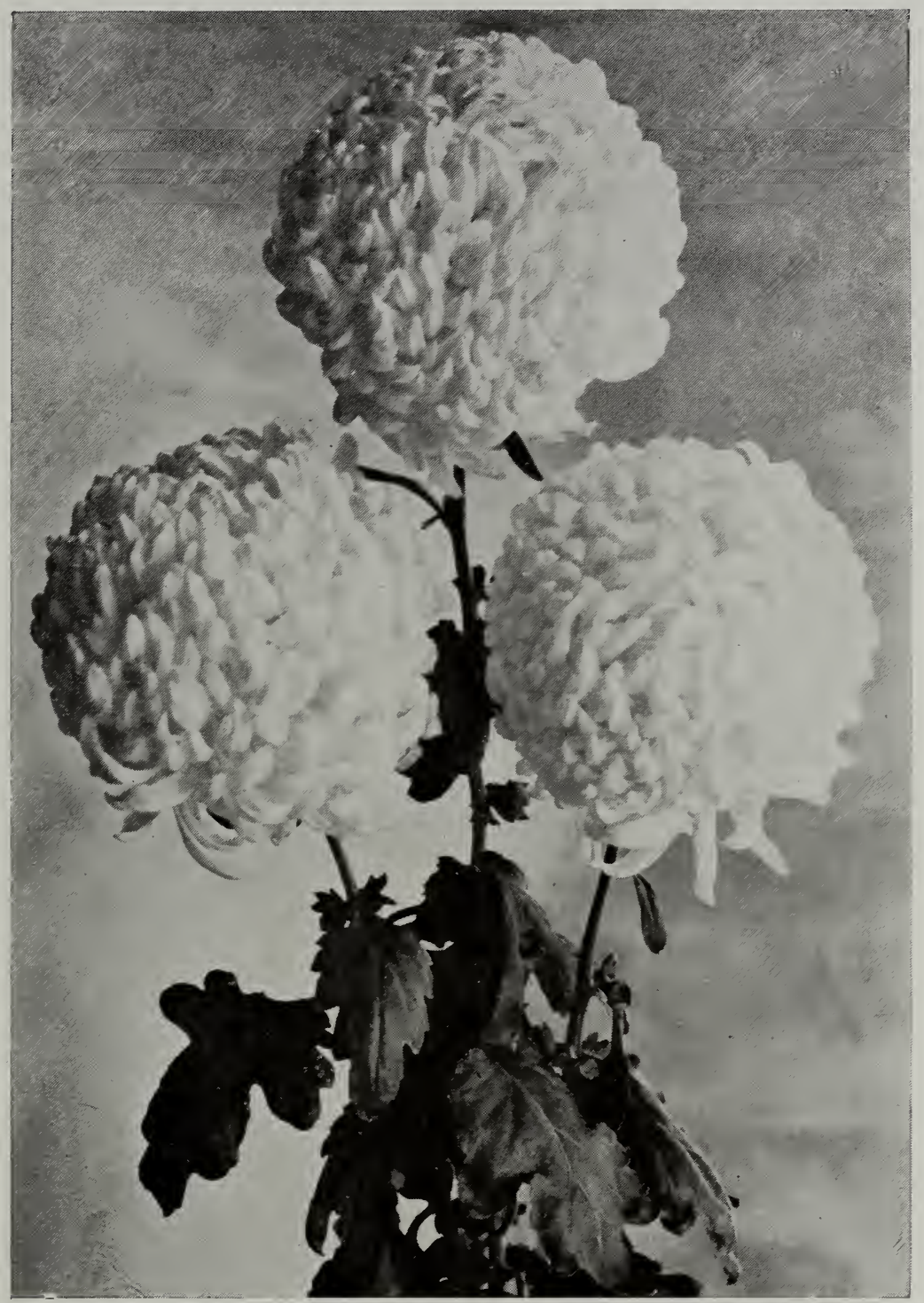

JOSEPHINE FOLEY. - Winner of Foley prize for best seedling at Indianapolis last year, and has been recommended for certificate by all five committees of the C. S. A. the past season. A seedling from Naomah but stronger and easier of propagation, purer white with the same high rounded incurved form, excellent stem and foliage. Splendid for exhibition from Aug. 25th buds and an exceptionally fine commercial from September buds, which produce perfectly double flowers. Matures last of October, $5 \mathrm{ft}$. from May plantings.

$75 \mathrm{c}$ each $; \$ 6.00$ per ten; $\$ 45.00$ per hundred. 


\section{INTRODUGTIONS OF 1915}

25 c each; $\$ 2.00$ per ten; $\$ 15.00$ per hundred, unless otherwise quoted.

Not less than 5 plants of a variety at ten, and 25 at hundred rate.

CRYSTAL GEM.-The best white for October 10th to 20th. Strong grower and easy to manage, giving a high percentage of perfect blooms. Good stem and foliage. Bud Aug. 15th.

EARLY FROST.-A new early white of great promise. Last year's buyers speak of it in the highest terms. Will be in strong demand. Difficult of early propagation.

GOLDEN QUEEN.-The best yellow for early October, maturing about the 10th. Same color as Golden Glow, fine incurved form and double from any bud. Strongly indorsed by last year's purchasers. Those who do not succeed with Golden Glow should try this fine yeliow. Best bud Aug. 10th.

MARIGOLD.-As a yellow is unsurpassed both as to size and color maturing: October 20 to 30th. A monster flower, being equally well adapted for early shows as for commercial use. Securing the bud Aug. 20th to 25th is the most important detail to insure success, otherwise the flowers are undersized and show the center.

MODELLO.-Most striking in color and form. Golden Amber. Like a hugh decorative Dahlia. Where artistic effects in orange are desired it has no equal. Easy to grow, maturing the first week in November. Bud Sept. 5th to 10 th.

TEKONSHA.-The best large flowering bronze for Thanksgiving. Coming just right for this event. Strong upright growth. Those desiring a late bronze should not overlook this variety. Bud September 10 th.

THE METAIRIE.-A very strong grower like Oconto producing a large reflexed white bloom October 25th.

WHITE CHIEFTAIN.-A white sport from Chieftain, has become very popular. $10 \mathrm{c}$ each; 80c fer ten; $\$ 6 . C 0$ per hundred.

\section{STANDARD VARIETIES}

\section{EARLY.}

To secure early flowers it is of the utmost importance that they be planted early. Good strong plants from 3-in. pots benched in May give very satisfactory results. In case the buds are not formed at the date given, reserve the first that appears thereafter.

10c each; 75c per ten; $\$ 5.60$ per hundred, except where otherwise quoted.

Not less than 5 plants of a variety at ten, 25 at hundred rate.

Height Bud

$48 / 20$

$48 / 20$

$48 / 20$

Alice salomon.-A large incurved white. Maturing about October 20 th. Very desirable owing to its size and earliness.

Chas. Rager.-Pure white incurved, producing a high percentage of perfect blooms.

Chryslora.- (Introduced by us in 1911.) The best yellow for early October. Fine incurved form with perfect stem and foliage to the bloom. Also useful for early exhibitions. 


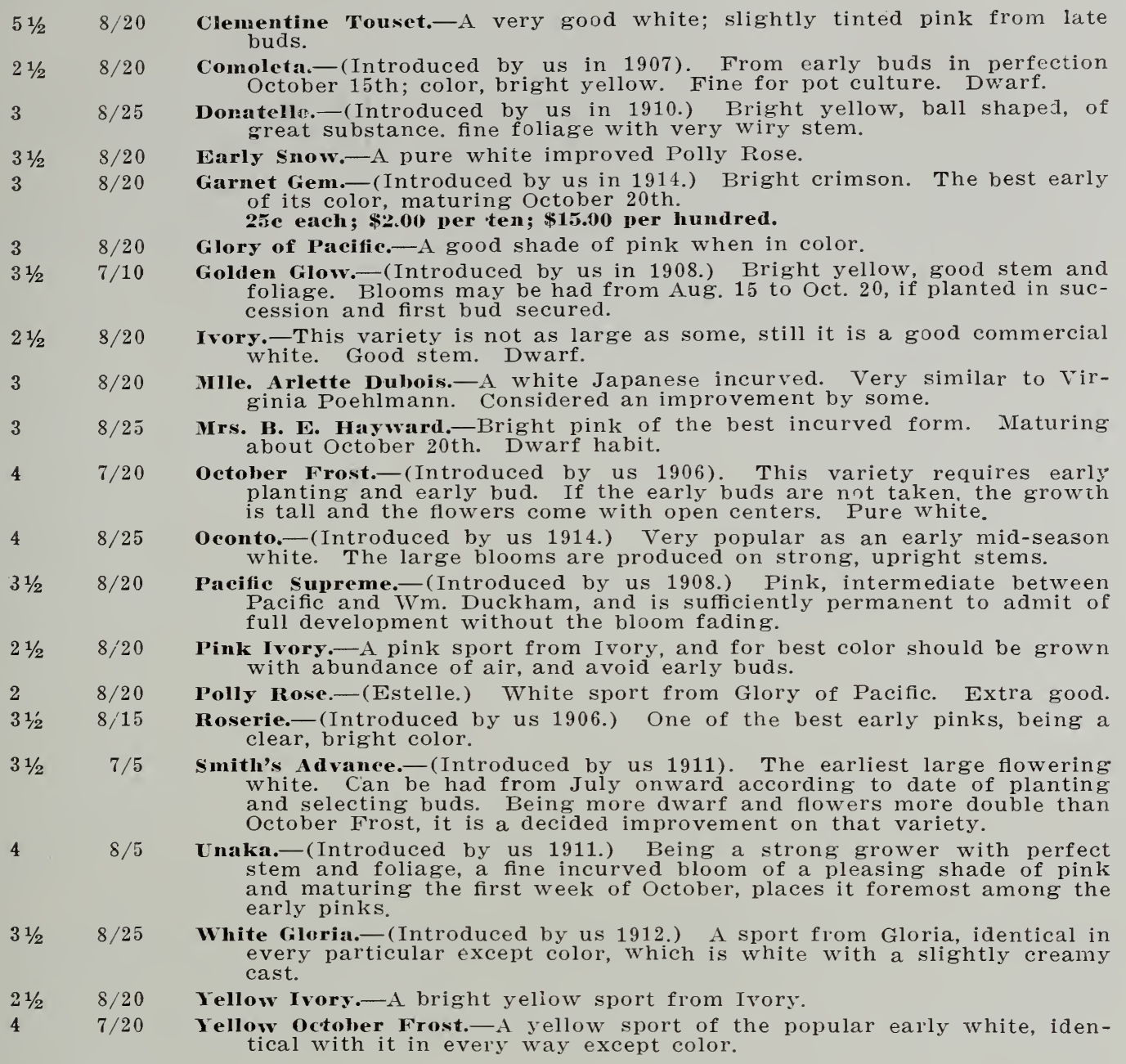

\section{MID-SEASON.}

In giving the height of mid-season varieties we have based our estimate on good, strong plants, benched June 15th. In favorab?e seasons some of the varieties will perfect blooms a few days before November 1st, and as climatic conditions have much to do with flowering seascn, the figures given must not re considered infallible.

10c each; 75c per ten; $\$ 5.00$ per hundred, except where otherwise quoted.

Not less than 5 plants of a variety at ten, 25 at hundred rate.

Height Bud

\begin{tabular}{|c|c|}
\hline 4 & $8 / 30$ \\
\hline 5 & $9 / 15$ \\
\hline 4 & $8 / 25$ \\
\hline $31 / 2$ & $8 / 20$ \\
\hline 4 & $9 / 15$ \\
\hline 4 & $9 / 5$ \\
\hline & $9 / 10$ \\
\hline
\end{tabular}

Chieftain.-Probably the most popular pink among tho growers and will be grown in large quantities the coming season. Good in every way.

Col. D. Appleton. - One of the best yellows for commercial and exhibition use.

Dick Witterstacter.-(Introduced by us 1911.) A beautiful shade of bright crimson; blooms reflex and show the crimson to best advantage. Should be planted not later than June 15 th to secure bud August 25 th for best results.

Dolly Dimple.-A fine, large, well built yellow variety; strong grower with good foliage.

Golden Eagle.-Very intense yellow, wide petals, incurved form, one of the finest.

Golden Eaton.- A golden yellow sport from Eaton. A great improvement over the old variety.

15e each; \$1.20 per ten; $\$ 10.00$ per hundred.

Golden Wedding.-Loosely incurved, bright yellow.

Hircndelle.-A striking shade of bright rose color. Good stem and foliage. 


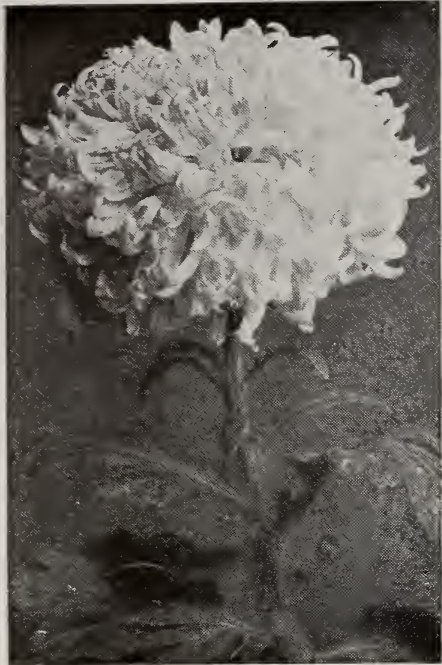

Crystal Gem.

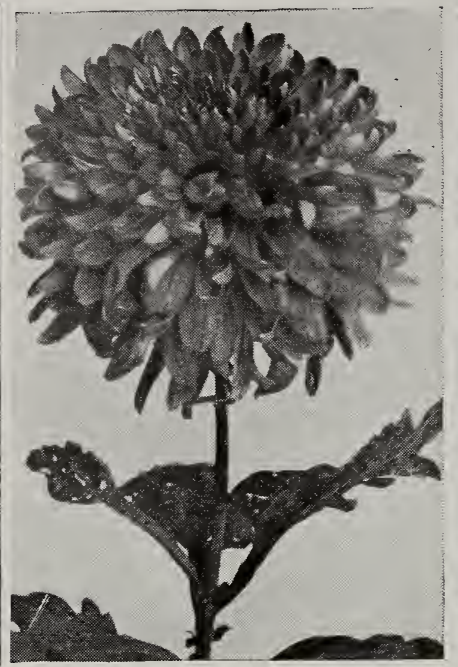

Modello.

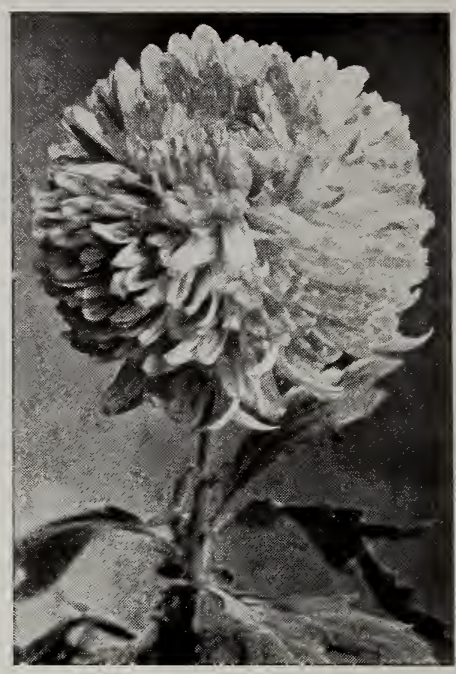

Golden Queen.

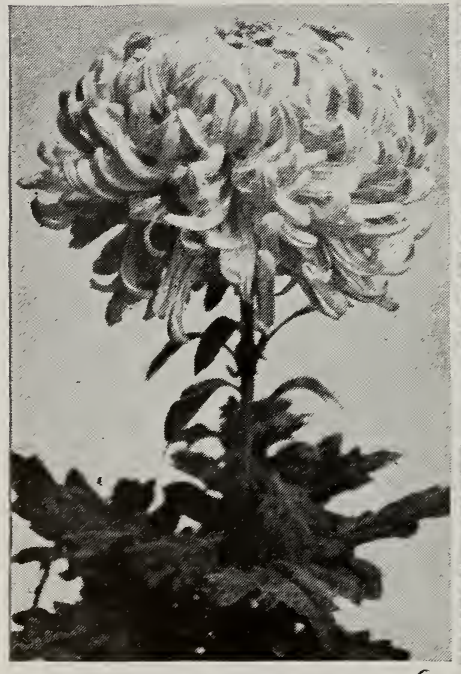

Marigold.

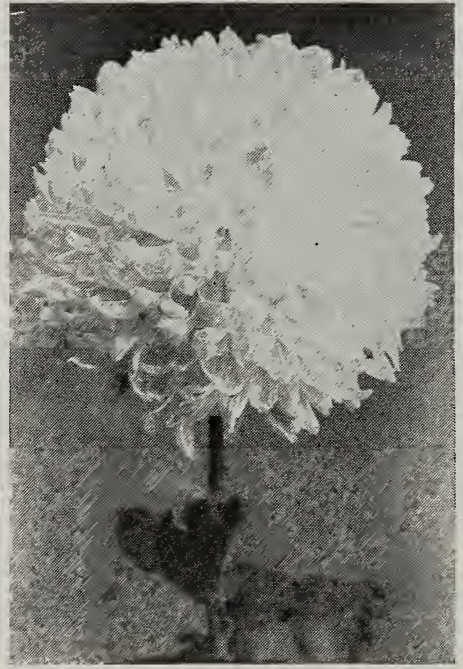

oeonto.

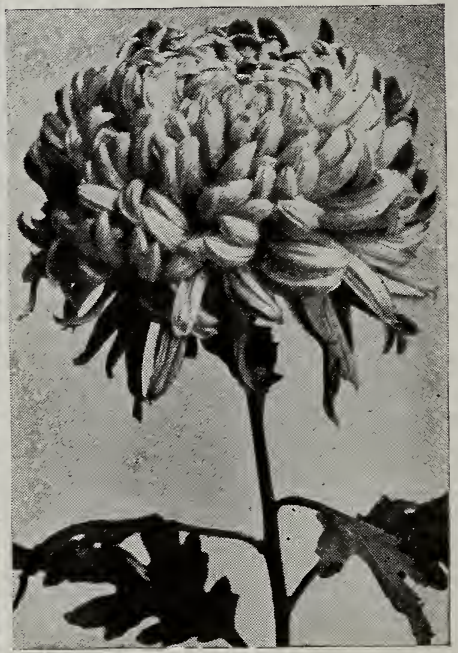

Tekonsha.

Smith's Chrysanthemum Manual leads to success. Price 50c postpaid. See inside last cover.

Owing to the frequent delays in delivery by parcel post, we will not adjust claims from this cause. Purchasers must be responsible.

Those desiring a soluble fertilizer especially prepared for the production of highest grade of chrysanthemum blooms are referred to inside of last cover. 
$8 / 25$

$31 / 2 \quad 8 / 25$

$4 \quad 8 / 20$

$21 / 2 \quad 8 / 25$

$4 \quad 9 / 5$

$3 \quad 9 / 5$

$4 \quad 8 / 20$

$+\quad 8 / 25$

Mary E. Meyer.-(Introduced by us 1913.) Purest paper white, short jointed growth, being especially adapted to commercial use. Has been well received the past season.

Mrs. H. Robinson. - Incurved white, good for single stem pot plants.

Naomah.-(Introduced by us 1910.) Its pure white, perfect incurved blooms and fine stem and foliage give it first place among the commercial whites.

15e each; $\$ 1.20$ per ten; $\$ 10.00$ per hundred.

Patty.-A beautiful Enchantress pink Japanese; dwarf. This is very fine both in color and habit; does not fade.

Pink Gem.- (Introduced by us 1912.) A pleasing shade of light pink, perfect form, ideal stem and foliage, and wonderful substance.

Pres. Roosevelt.-(Introduced by us 1906.) Very short jointed, requires early planting to secure long stems; beautiful incurved form, stem and foliage ample. Blush with darker center petals.

Ramapo.-Color of Col. D. Appleton; splendid foliage up to the bloom; does not show the raised center as Appleton. A first-class yellow.

Roman Gold.- (Introduced by us 1911.) A very intense yellow, maturing November $1 \mathrm{st}$ to 10 th. Perfect stem and foliage, easy to manage. From late buds they show the bronzy tints in the depths of petals, but this rather adds to their beauty.

Smith's Ideal.-(Introduced by us 1914.) A companion for Major Bonnaffon, producing the same perfect formed blooms of pure white, about November $1 \mathrm{st}$.

$15 c$ each; $\$ 1.20$ per ten; $\$ 10.00$ per hundred.

Smith's Sensation.-(Introduced by us 1912.) A delicate shade of pink, of fine incurved form.

9/5 Tim Eaton.-Large incurved white Japanese, equally serviceable for exhibition or commercial use.

9/10 Viviand Morel.-An old variety of reflexed type; flowers large and of a pleasing shade of bright pink.

White Perfection.- (Introduced by us 1913.) High rounded incurved, of exceptional depth and purest white. Fine shipper and keeper; one of the very best whites for Thanksgiving use.

Yellow Eaton.-Large incurved sport from Tim Eaton. equally serviceable for exhibition or commercial use.

\section{LATE.}

Some of the late varieties mentioned will perfect flowers by November 10 th, if early buds are secured and the season is favorable. On the other hand they may be retarded by planting late and securing late buds.

10 c each; 75 c per ten; $\$ 5.00$ per hundred.

Not less than 5 plants of a variety at ten, 25 at hundred rate.

Height Bud

$5 \quad 9 / 5$

$9 / 5$

5

4

$9 / 15$

Adonis.-(Introduced by us 1910.) Is well adapted for commercial use; also for late exhibitions. An exquisite shade of pink, and double from late buds.

Antique.- A deep bronze sport from Dr. Enguehard; a duplicate of Enguehard in all respects save color.

Chadwick Improved.- (Introduced by us 1909.) A pure white sport from W. H. Chadwick. Japanese incurved.

Chadwick Supreme.-In color, bright pink; in form, reflexed; of Viviand Morel type, and in habit is a duplicate of $T$. H. Chadwick, the variety from which it is a sport.

December Gem.- (Introduced by us 1911.) This variety blooms from the last of November to the middle of December, according to date of buds. White, with a slight pink tinge. Ball shaped. Very stiff, wiry stem.

Dr. Ensuehard.-Bright rose pink double from either bud; while those from the late buds are somewhat smaller, they are greatly improved in color.

Edvin Seidewitz.-A beautiful late, incurved, bright pink, maturing from Thanksgiving to early December. Surpasses all late pinks we have grown.

Golden Chadwick.-Yellow sport from W. H. Chadwick. By planting late may be had for Thanksgiving or later.

Harvard.- (Introduced by us 1912.) Japanese reflexed, very dark crimson. In perfection November 15 th or later. The best red yet introduced; double from any bud.

Helen Frick.-(Introduced by us 1904.) A fine, late, dark pink Japanese incurved; stem and foliage good.

Jeanne Nonin.-Another fine late white, with large incurved blooms. The early buds give rather coarse flowe:s, and to our mind not as fine in form as from the later ones.

Major Bonnafion.-A fine yellow, easy of cultivation and incurved form.

Mistletoe.-Blush white; strong, upright growth. One of the latest; not ready to cut until December.

White Bonnaffon.- (Introduced by us 1900.) Incurved white; still grown in quantity.

White Helen Frick.-(Introduced by us 1910.) A very desirable late white, coming for Thanksgiving and later. Dwarf habit.

w. H. Chadwick.-Large incurved white, sometimes shaded pink. 


\section{POMPON SECTION}

Pompons are becoming more popular year by year, being especially desirable for pot plants, and lend a distinctive grace and keauty to floral decorations of all kinds.

\section{New American Chrysanthemums for 1916 Originated by Elmer D. Smith \& CO.}

Price.-45c each; $\$ 3.75$ per ten; $\$ 30.00$ per hundred.

Delivery on or before March 1st. Not less than 5 plants of a variety at ten and 25 at hundred rate.

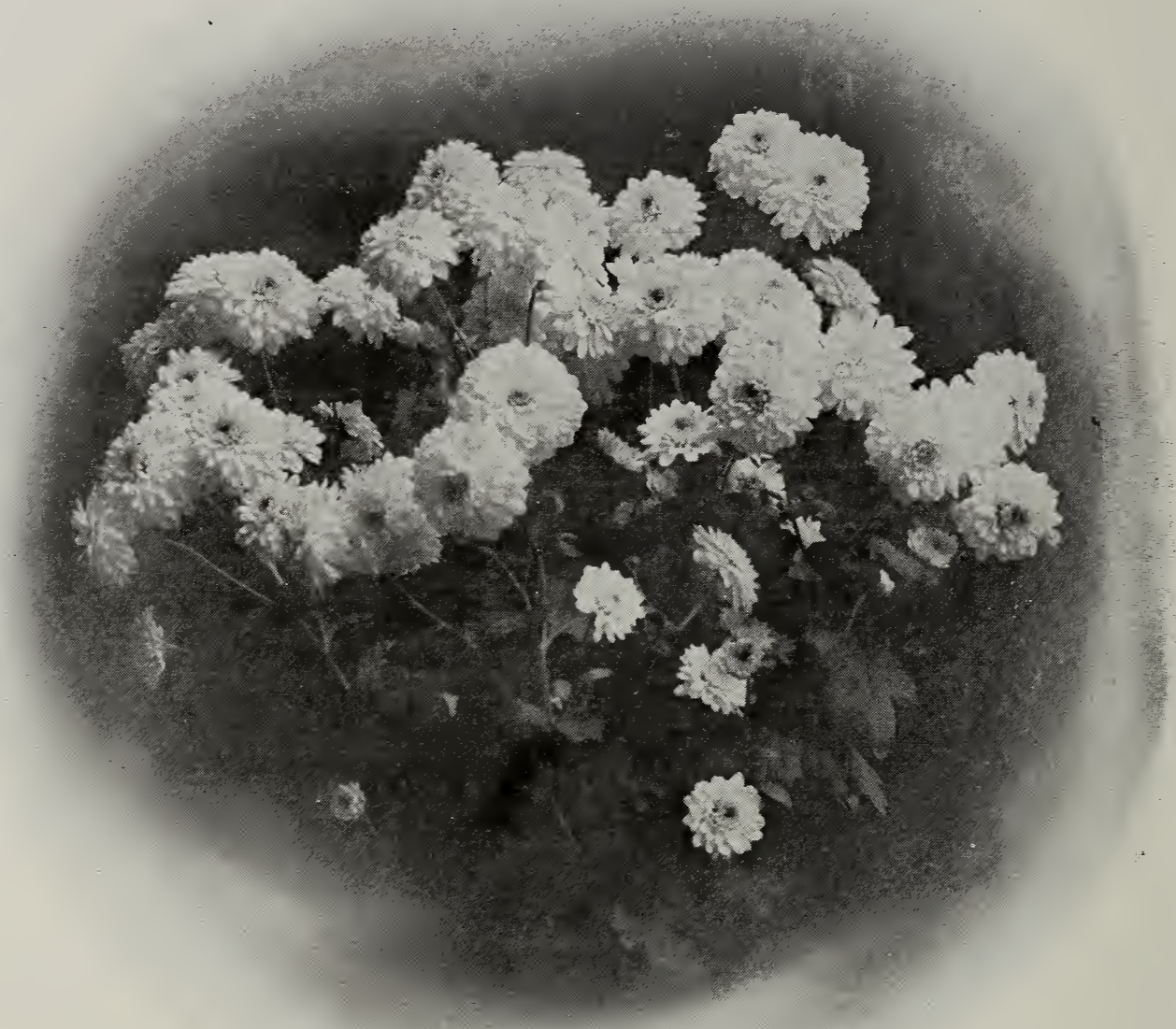

NORDI.-A pure white Pompon maturing Nov. 10th to Thanksgiving. Seven to eight medium sized flowers to the spray, with strong wiry stem. From equal space this variety will double the quantity of sprays to those produced by either Helen Newberry or Lulu the best two late white Pompons in commerce.

ZORA.-This variety we were unable to disseminate last year owing to the misfortune of losing most of stock. An early bright yellow maturing October 15th to 20th, nice large sprays coming a few days ahead of Zenobia. This is the earliest good yellow Pompon we know of. 


\section{Elmer D. Smith \&
Novelties for 1916}

\section{COMMERCIAL SECTION}

Early Rose.-A seedling from Smith's Advance. Rose color, as the name implies, of a bright pleasing shade under all conditions of light. Form incurved, size six inches. Stem and foliage excellent. Dwarf habit $2^{1 / 2}$ to $3 \mathrm{ft}$. high. There are but few pinks maturing before October $15 \mathrm{th}$ and most of these are unsatisfactory unless the bud is selected at the proper date, being off-colored if too early or single from late buds. Best bud Aug. 20th, producing fully matured flowers in six weeks and double from all buds this date and later. C. S. A. Certificate.

October Queen.-This belongs to the Japanese section with an inclination to incurve at the center, especially from September buds. One of the purest whites we know of. Maturing October 15th, height $5 \mathrm{ft}$. This variety has been scored 93 points. Having been given full number on color, stem and foliage. Best bud Aug. 25th.

Tiger.-Pres. Wilson kindly supplied the name for this new yellow. A seedling from Chrysolora being several shades darker than its parent. It is supremely fitted for the rank and file of growers, especially those who are unable to plant early, as its characteristics stamp it as a commercial of special merit. Fine incurved form, producing flowers double to the center from September buds, sturdy semi-dwarf growth, with beautiful foliage and very rigid stem. Height about $4 \mathrm{ft}$, from June 1st plantings. Best bud September 5 th. C. S. A. Certiflcate.

Josephine Foley.-Winner of Foley prize for best seedling at Indianapolis last year and has been recommended for certificate by all five committees of the C. S. A. the past season. A seedling from Naomah but stronger and easier of propagation, purer white with the same high rounded incurved form, excellent stem and foliage. Splendid for exhibition from Aug. 25th buds and an exceptionally fine commercial from September buds, which produce perfectly double flowers. Matures last of October, $5 \mathrm{ft}$. from May plantings.

Price. $-75 \phi$ each; $\$ 6.00$ per ten; $\$ 15.00$ per hundred.

Delivery on or before March 1st, 1916 according to productiveness and demand. Not less than 5 plants of variety at ten and 25 at hundred rate.

\section{POMPON SECTION}

Nordi.-A pure white Pompon maturing Nov. 10th to Thanksgiving. Seven to eight medium sized flowers to the spray, with strong wiry stem. From equal space this variety will double the quantity of sprays to those produced by either Helen Newberry or Lulu the best two late white Pompons in commerce.

Zora.-This variety we were unable to disseminate last year owing to the misfortune of losing most of stock. An early bright yellow maturing October 15th to 20th, nice large sprays coming a few days ahead of Zenobia. This is the earliest good yellow Pompon we know of.

Price. $-45 \phi$ each; $\$ 3.75$ per ten; $\$ 30: 00$ per hundred.

Delivery on or before March 1st, 1916. Not less than 5 plants of a variety at ten and 25 at hundred rate. 


\section{EXHIBITION SECTION}

Artista.-This we believe is the largest Exhibition variety we have ever raised and doubt if it will be surpassed by any now grown, not excepting Wm. Turner, Odessa, etc. Outer petals grooved or channeled refiex while the center ones incurve irregularly giving a very artistic appearance to the bloom. Dwarf habit, will not attain over $5 \mathrm{ft}$. from February propagation. White with a slightly creamy tint in the depths. Best bud August 20th, maturing the last days of October. All exhibition growers are bound to accept this as one of the best.

Ogontz. - A seedling from Nakota which it greatly resembles in foliage, and has the same whirling arrangement of petals, with size equal to its parent. The petals are decidedly grooved or channeled. Color, light primrose, height $6 \mathrm{ft}$. Would not advise a bud earlier than August 30 th as the blooms are double from those selected in September. Practícally the same as Nakota except color, maturing first week of November. May also be advantageously grown as a commercial maturing November 20 th from buds taken September 20 th and after.

Price.- $\$ 1.50$ each; $\$ 12.50$ per ten; $\$ 100.00$ per hundred.

Delivery on or before February 1st, 1916. Not less than 5 plants of a variety at ten and 25 at hundred rate.

\section{ANNOUNGEMENT}

The new Chrysanthemum shown as Smith's Cameo was awarded the sweepstakes prize in the Seedling classes at both Cleveland and Chicago and has been greatly admired by thousands of persons attending these shows. We consider it one of our greatest achievements and those in the trade referred to it as the best seedling of the year. Upon investigation recent tests have given positive proof it is inclined to shatter or drop its petals. This serious defect disqualifies it as a shipper and for this reason alone we have decided much to our regret that it is unworthy of our indorsement and dissemination. Justice to our patrons is justice to ourselves and we feel assured the course taken will be appreciated.

Lithe Gem.-Certificated at Cleveland, will not be disseminated until 1917 owing to limited stock. Will however be pleased to book your order one year in advance at same price quoted on Nordi or Zora.

Soliciting your early orders we are,

Very sincerely yours,

ELMER D. SMITH \& CO.

Adrian, Mich. 


\section{INTRODUGTIONS OF 1915}

15 c each; $\$ 1.00$ per ten; $\$ 7.50$ per hundred.

Not less than 5 plants of a variety at ten, 25 at hundred rate.

Harrest Icon.-Golden yellow, maturing October 25th. very free flowering. Medium sized flowers. Dwarf.

Illona.- (Introduced by us 1915.) Rosy lavender, much the same color as Western Beauty but produces larger sprays, hence is more profitable. Large; height medium. Nov. 10 th.

Neola.-(Introduced by us 1915.) Light pink, strong growth with a stem like Quinola; needs very little tying. Large, maturing Nov. 15 th to 25 th. Dwarf.

Niza.-(Introduced by us 1915.) Delicate pink and the earliest of this color, maturing Oct. 10th. Those desiring early Pompons should secure this variety. Medium sized flowers. Dwarf.

Rodi.-(Introduced by us 1915.) The best of its color, purplish rose. Large, strong, upright growth. Tall.

Veta.-(Introduced by us 1915.) Small, pure white flowers; very free. Resembles the old variety Snow Drops, but produces much larger sprays; will supercede Baby Margue. rite. Dwarf.

\section{STANDARD VARIETIES}

10c each; 75 c per ten; \$5.C0 per hundred.

Not less than 5 plants of a varicty at ten, 25 at hundred rate.

Acto.-(Introduced by us 1901.) Bright rose with lighter reverse. Dahlia-like petals.

Alma.-(Introduced by us 1907.) A very free growing, large flowered variety; clear, soft lavender pink.

Baby.-Clear bright yellow; very late.

Baby Marguerite.-A pure white sport from Baby.

Celco.-(Introduced by us 1914.) Bright yellow, approaching orange; similar to that of Golden Climax, only a little flatter in form, but will produce two to three times as many flowers to an equal space. Medium sized. Tall.

Clorinda.- (Introduced by us 1910.) Semi-dwarf, producing erect sprays of an even shade of bronze. One of the best for specimen plants.

Diana.-A fine pure white.

Fairy Queen.-A delightful deep Enchantress color, of medium size, round and full. elegant foliage and a good keeper.

Frank Wilcox.-(Syn. Mrs. Beu and Souv. d'Or). Golden bronze of special merit to those desiring late Pompons.

Golden Chmax.-A very pleasing shade of bright yellow; medium size and height.

Golden Harvest. - Very similar to Golden Climax̃, except it has a tinge of bronze added to the yellow.

Golden West.-A small golden yellow flower of great substance. Dwarf.

Helen Newbery.-The latest white Pompon; just as good and a little better than the popular variety Diana, which it follows for Thanksgiving and up to Christmas.

Insa.-(Introduced by us 1907.) Bright red, maturing October 20 th; fine form; medium in size and height.

Iva.- (Introduced by us 1908.) Pure amber; fimbriated petals; medium size.

Julie Lagravere.-Deep red; best of its color. Late.

Klondike.-Brilliant yellow; compact blooms of medium size.

La Iurite.-A beautiful pure white.

Leota.-(Introduced by us 1914.) Delicate pink, maturing October 20th, and produces large, full sprays; one of the very best; medium size. Dwarf.

Lillia.-Deep bronzy red; tall, upright growth; medium size. 
Lillian Doty.-Flowers beautiful shell pink, best grown to several leads and disbudded to one bloom. Strong, upright growth.

Lodi.-(Introduced by us 1907.) Large clear yellow; cupped petals; very double.

Lulu.-Pure snow white of medium size. Late.

Madge.-Very perfect in form. golden yellow, same shade as Golden Harvest and the best of the two. Medium size. Dwarf.

Minta.-(Introduced by us 1911.) A very free flowering light pink, unsurpassed by any of this color. Owing to its upright growth it is one of the best for specimen plants.

Nesco.-(Introduced by us 1914.) Old rose, of fine form; medium size. Dwarf.

Nio.-(Introduced by us 1907.) Soft pink and white at center.

Quinola.-Clear orange yellow; excellent form and good size.

Skibo.-(Introduced by us 1905.) Golden chamois; flowers small.

Utan.-(Introduced by us 1902.) Light magenta, edged white.

Western Beauty.-Flower large, deep rose pink, stiff, upright growth.

White Jitsu-jetui.-Purest white; has wonderful substance; petals thick and heavy and rolled like cord, with tightly incurved center.

Zenobia.-Bright, clear yellow. Early.

\section{ANEMONES.}

The Anemone flowers consist of one or more rows of flat or tubular ray florets, with shorter quilled or tubular disc florets of the same or distinct color; are being grown in sprays for artistic floral arrangements. For specimen blooms those marked "large flowering" are best and resort to disbudding to increase the size.

\section{NEW VARIETIES.}

Golden Lida Thomas.-A golden yellow sport from Lida Thomas, and, like its parent, matures just right for Thanksgiving. Good in every way. We consider this the best for florists' use. 25e each; $\$ 2.00$ per ten; $\$ 15.00$ per hundred.

Godfrey's Perfection.-Resembles Garza, being same size and pure white, but is a better shipper, having four or five rows of ray florets instead of one. Matures for Thanksgiving and is one of the best of recent introductions. Dwarf, making excellent pot plants. 25c each; $\$ 2.00$ per ten; $\$ 15.00$ per hundred.

\section{STANDARD VARIETIES}

10c each; 75c per ten; $\$ 5.00$ per hundred.

Not less than 5 plants of a variety at ten, 25 at hundred rate.

Alpine Glow.-Large white flower with a glow of pink; very beautiful.

Ada Sweet.-Silvery pink, medium size flower; petals mostly quilled; fine for pots.

Azelda.-(Introduced by us 1914.) Light pink, shaded lavender; rays and disc florets same shade, except center of cushion, which is cream color.

Beatrice Asmus.-Beautiful pure white petals; flat and substantial.

Bessie Flight.-Bright, rosy pink, center full. A sport from Mme. Montels.

Diantha.- (Introduced by us 1913.). Dwarf, compact growth; fine for small pot plant or to grow for sprays. Guard white, high rounded cream-colored center.

Garza.-Purest white with yellow center; medium size; rays broad.

Laurita.-(Introduced by us 1913.) Bright yellow; very useful as a small pot plant or to grow for sprays.

Lida Thomas.-Small flower, white, two rows of flat petals, center delicate yellow; late.

Mary Colladay.-A seedling of Garza, with habit of parent; in color, a rich rosy lavender pink. Extremely free and of excellent keeping qualities.

Miss Katherine Simmons.- Soft pink; one row of quilled petals loosely arranged; yellow center.

Miss Ida Kroeschell.-Light yellow, quilled petals loosely arranged; large center of deeper yellow.

Mrs. Jacob Wellauer.-Beautiful lilac color; flat petals; large honeycombed center.

Irs. Shimmins.-Apricot, shading to red. Belongs to the large flowering section. Semi-dwarf and free.

Princess.-Very similar to Garza, the principal difference being it has strap-shaped ray florets instead of semi-tubular. Is much freer of propagation and in our opinion better than Garza for general use.

Surprise.-Pink, very large and good.

Yellow Garza.-A yellow sport from Garza, identical in other respects. 


\section{SINGLES.}

This section comprises the best varieties for cut sprays and are also useful for specimen plants. Those listed below we consider best and have specified same.

10c each; 75c per ten; $\$ 5.00$ per hundred, unless otherwise quoted.

Not less than 5 plants of a variety at ten, 25 at hundred rate.

Allegheny.-Beautiful clear pink, similar to that of Ladysmith.

Anna.- (Introduced by us 1909.) Pure white; belongs to the true single section, having but one row of petals. Fine for pot plants.

Arlee,-(Introduced by us 1910.) A rich, golden amber of dwarf growth; excellent either as a pot plant or for cutting. Large flowering. cream.

Bishop Henninghaus.- Petals tubular, opening at the extremities. Red, tubes deep

Blazing Star.- (Introduced by us 1913.) The best bright single red to grow for sprays.

Caledonia.-Beautiful shade of pink and very useful for those retailing their crop; not a good shipper.

Catherine Livingstone.-A pleasing shade of lavender pink; strong grower and produces fine sprays.

Ceddie Mason.-A fine scarlet crimson; long stem; very free.

Celtic.-Rose pink, large flowers.

Clea.-(Introduced by us 1912.) Growth upright, forming large sprays of a delicate shade of light pink.

Gladys Duekham.-Very large white, coming ahead of Mensa.

Golden Mensa.--Doubtless the best single yellow for general purposes.

Golden star.-An old yellow, still popular with some.

Hilda Wells.- Bcautiful Tuscan red with a light yellow tinting at base of petals:

Indicum.-Yellow, very small. The original wild variety from China.

Itaska.- (Introduced by us 1910.) Bright pink, petals incurving like R. B. Burge; late.

Josephine.-A splendid single yellow of excepticnal merit.

Lady Lu.-L'urcst white; good for all purposes.

Ladysmith.-Early pink; useful for bush plants.

Little Barbee.-Clear canary yellow; exceptionally large sprays of medium sized flowers. This we consider the best yellow, either for cutiting or pot culture.

Mensa.-One of the largest single whites; produces freely on lonf, stiff stems.

Merstlam Jewel.- - Terra cotta, with golden points and center.

Minnesota.-A very striking blood red, $2 \frac{1}{2}$ in. across; long, slender stem; best red for general use.

Miss Isabe:le.-Bronzy amber sport from Mrs. E. D. Godfrey. Good for late cutting.

Mrs. E. D. Godfrey.-Very strong grower. Light pink. Excellent as a late single.

Mrs. Wm. Buckingham.-A large, flat flower of a lovely shade of rosy pink, and keeps well, both on or off the plant.

Po!ly Duncan.-Canary yellow; large flower, borne erect; very desirable.

Queen.-(Introduced by us 1913.) The best late single white, maturing from Thanksgiving into December.

R. B. Burge.-Yurest write, petals incurved. difficult of propagation.

Rcb Roy.-Very light blush on white ground.

Royalty.-(Ncw 1915.) Light crimson, almost scarlet; for Thanksgiving and later. $25 \mathrm{c}$ each; $\$ 2.00$ per ten; $\$ 15.00$ per hundred.

Eanley Ven.-Rose color, producing loose and graceful sprays. One of the best.

Sylvia slade.-Rosy garnet, with white ring around the disc; distinct and good

Tasso.-(Introduced by us 1913.) Early, delicate pink, very dwarf and free. 


\section{EARLY HARDY SECTION.}

The majority of Chrysanthemums are hardy south of the Ohio river and many are hardy in the northern states, as far as the plant is concerned, but they must flower before early frosts to be of service. The varieties offered below generally flower from the last of August to the 15th of October.

$10 \mathrm{c}$ each; $80 \mathrm{c}$ per ten; $\$ 6.00$ per hundred.

Not less than 5 plants of a varity at ten, 25 at hundred rate.

The small or Pompon varieties are so indicated in the descriptions, the others have larger flowers more like Asters.

Boston.- Strong upright growth, clear bronze.

Cactus. - Fiery terra cotta, shape of a small cactus, very free and effective.

Carrie (Syn. Glory of Seven Oaks.) - Deep yellow; a beauty.

Chaldron.-Reddish crimson with gold tips. Large flower.

Champagne.-Bright ruby red; wonderfully colored.

Champ d.Or.-Canary yellow; very bushy habit. tion.

Daisy. - A pure white daisy-like flower, belongs to the Pompon or small flowered sec-

Eden.-Bright rose; a beauty disbudded. free.

Gold Nugget.-Belongs to the Pompon section. Yellow streaked bronze. Early and

Hermine.-A pure white, reflexed.

Holmes White.-Pure white, dwarf and very hardy.

Lady Mary Hope.-White, slightly shaded blush; good habit.

Le Pactole.-Bronzy yellow, large flower, strong grower.

Little Bob. - Small red flowers, very free and pretty; belongs to the Pompon section.

Miss F. Collier.-Pure waxy white. Sturdy dwarf growth.

Irs. Porter.-Large reddish bronze; strong grower.

Petite Louis.-Silvery mauve, very robust; one of the best. onward.

Winnetka.-(Introduced by us 1914.) Pure white, very free flowering from July

\section{HAIRY VARIETIES.}

These curious and unique flowers, with their petals covered with frost-like hairs, are always of great interest to visitors. They should be represented in all collections where friends or the public have access. They are not adapted to commercial use, and not of sufficient size to become prominent features on the show table, unless the schedule provides for this specific type.

$10 \mathrm{c}$ each; 80c per ten; $\$ 6.00$ per hundred.

Not less than 5 plants of a variety at ten, 25 at hundred rate.

Arvede Barine.-Beautiful lavender pink, very heavily plumed.

Beauty of Truro.-A purplish bronze sport $\mathrm{f}$. om Louis Boehmer.

Frison d'Or.-An incurved bloom of reddish bronze, with markings of yellow.

L'Enfant des deaux Mondes.-Pure white sport from Louis Boehmer.

Louis Boehmer.-Magenta pink. This and its sports are excellent for bush culture.

\section{DECORATIVE SECTION}

The following varieties are especially adapted for the production of large or small specimen plants. Where large specimens are required, they should be started in January or February. Medium sized plants can be produced from cuttings struck in March, and for those who desire to grow small sizes for market trade, this work may be continued until the middle of June.

10c each; 80c per ten; $\$ 6.60$ per hundred.

Not less than 5 plants of a variety at ten, 25 at hundred rate.

August Dasse.-Very solid flower of excellent keeping quality, globular in form; coior, intense yellow. Dwarf.

Brutus.-Beautiful shade of bronze, most useful as a specimen plant. Dwarf.

Butler's Caprice.-Sport of Caprice du Printemps. Deep pink. Dwarf.

Golden Ige.- (Introduced by us 1904.) Brightest yellow, excellent for specimen plants and is becoming more popular each year for this purpose. Dwarf.

Golden Robin.- (Introduced by us 1913.) An improved Golden Age, either as a specimen plant or for commercial yellow. Golden Wedding is light yellow by comparison. Dwarf.

Greystone,-This variety comes highly recommended as one of the best for specimen plants. Color, beautiful golden orange. Dwarf.

Kathleen Thompson.-A fine crimson. Dwarf.

Lady Lydia.-Pure white. Dwarf.

Lilac Caprice.-Deep lilac. Dwarf.

Purple Caprice.-Purple. Dwarf.

White Caprice.-White. Dwarf.

W. H. Lincoln.- An old variety but still sought by some for specimens and late marliet plants. Yellow.

Icllow Caprice-Clear yellow. Dwarf. 


\section{Smith's}

\section{Revised Chrysanthemum Manual}

(THIRD EDITION.)

By ELMER D. SMITH

Who has made a Specialty of Chrysanthemum Culture for the past Twenty-five Years.

This booklet treats the subject in a concise yet.lucid manner, covering the whole work from the care of stock plants to the staging of blooms.

The best work on American Chrysanthemum Culture. Both amateur and florists

have been provided with articles for their special needs.

\section{Chrysaline The Ideal Plant Food}

\section{Unequalled for Producing Lusty Chrysanthemums}

A complete Chemical Fertilizer, perfectly soluble and contains the same constituents as' those incorporated in manure, supplying proper quantities of nitrogen, potash and phosphoric acid, which are the most important elements conducive to plant life. food.

Stable manure contains less than $2 \%$, whi'e Chrysaline contains $65 \%$ actual plant

The analysis given by the State Chemist is as follows: Nitrogen, 13.3\%; Potash, $24.4 \%$; phosphoric acid, $28 \%$; total, $65 \%$ available plant food.

The advantages of Chrysaline over other manures are: It is clean, has no offensive odor, is soluble and thus easily prepared, is immediate and permanent in its effects, so highly concentrated that it is the cheapest, saves time and labor, and gives accurate results.

Samples of 14 ounces, prepaid by mail, $50 \mathrm{c}$.

Larger quantities will be furnished as follows:

Five pounds, $\$ 2.25$; Ten pounds, $\$ 4.50$; Twenty-five pounds, $\$ 8.75$; Fifty pounds, $\$ 15.00$. F. O. B. Adrian.

One ounce is sufficient for ten gallons. Full directions accompany each package.

Prepared and sold only by

ELMER D. SMITH \& CO., Adrian, Mich. 


\section{ELMER D. SMITH \& CO.}

Chrysanthemum Specialists

\section{Originators and Disseminators}

THE ONLY FIRM IN AMERICA GROWING CHRYSANTHEMUMS EXCLUSIVELY 